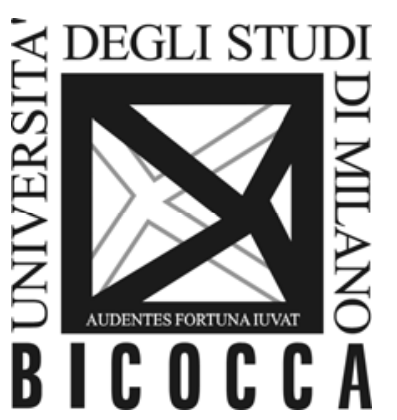

\author{
DEPARTMENT OF ECONOMICS, \\ MANAGEMENT AND STATISTICS \\ UNIVERSITY OF MILAN - BICOCCA
}

DEMS WORKING PAPER SERIES

\title{
Managerial compensation, regulation and risk in banks: theory and evidence from the financial crisis
}

\author{
Vittoria Cerasi, Tommaso Oliviero
}

No. 279 - July 2014

Dipartimento di Economia, Metodi Quantitativi e Strategie di Impresa Università degli Studi di Milano - Bicocca http://dems.unimib.it/ 


\title{
Managerial compensation, regulation and risk in banks: theory and evidence from the financial crisis *
}

\author{
Vittoria Cerasi $^{\dagger} \quad$ Tommaso Oliviero ${ }^{\dagger}$
}

This version: July 20, 2014

\begin{abstract}
This paper analyzes the relation between CEOs monetary incentives, financial regulation and risk in banks. We present a model where banks lend to opaque entrepreneurial projects to be monitored by managers; managers are remunerated according to a pay-for-performance scheme and their effort is unobservable to depositors and shareholders. Within a prudential regulatory framework that defines a capital requirement and a deposit insurance, we study the effect of increasing the variable component of managerial compensation on risk taking. We then test empirically how monetary incentives provided to CEOs in 2006 affected banks' stock price and volatility during the 2007-2008 financial crisis on a sample of large banks around the World. The cross-country dimension of our sample allows us to study the interaction between CEO incentives and financial regulation. The empirical analysis suggests that the sensitivity of CEOs equity portfolios to stock prices and volatility has been indeed related to worse performance in countries with explicit deposit insurance and weaker monitoring by shareholders. This evidence is coherent with the main prediction of the model, that is, the variable part of the managerial compensation, combined with weak insiders' monitoring, exacerbates the risk-shifting attitude by managers.
\end{abstract}

JEL classification:G21; G38.

Keywords: managerial compensation, risk taking, financial regulation, monitoring

${ }^{*}$ We thank Franklin Allen, Elena Carletti, Andrew Ellul, Nicola Pavoni and participants at the Workshop on Institutions, Individual Behavior and Economic Outcomes, Alghero - June 2014; at the Ifabs 6th international conference, Lisbon - June 2014. We are grateful to the Wharton Business School, University of Pennsylvania, since it was during a post-doc visiting period that it was possible to collect the data for this project. We gratefully aknowledge financial support from Einaudi Institute for Economics and Finance (EIEF Research Grant, 2013). All errors remain our own.

${ }^{\dagger}$ Corresponding author - University of Milan, Bicocca - Department of Economics, Quantitative Methods and Business Strategies (DEMS), Via Bicocca degli Arcimboldi 8, 20126 Milano, Italy, vittoria.cerasi@unimib.it

${ }^{\ddagger} \mathrm{CSEF}$, Italy, mroliviero@gmail.com 


\section{Introduction}

The recent world-wide recession has highlighted how capital market failures may represent an important driver of economic downturns. In particular after the 20072009 financial crisis there seems to be a widespread consensus among researchers and practitioners that financial institutions took too much risk at the onset of the crisis, despite risk management arrangements and solvency regulation (Diamond and Rajan (2009)). In particular, monetary incentives given to executives have been identified as one of the possible culprits of the failure of governance in the banking industry. In the recent past, executive compensation tied to firm performance in their various forms, such as bonuses related to firm value, stock options, or equity-plans have become standard tools of managerial remuneration in all sectors, and especially in banking. ${ }^{1}$ Given this growing importance of CEOs variable compensation we need to better understand its impact on risk-taking incentives in banks. In this paper we focus on the agency conflicts inside and outside the bank - shareholders vs. managers and depositors - to study the determinants of risk-taking and its interaction with financial regulation in a framework where managers are paid with variable compensation and their effort is not observable. We gain insights from a theoretical model to explore empirically the relation between CEOs monetary incentives and bank performance in a sample of banks based in different countries facing heterogeneous regulations.

We contribute to different areas in the literature. The corporate finance literature acknowledges the effect of leverage on risk shifting and the conflict between shareholders and debtholders (Jensen and Meckling (1976)). Seminal contributions by John and John (1993), and more recently by John et al. (2010), shed light on the relation between pay-for-performance sensitivity of executive compensation and bank leverage. More recently, Benmelech et al. (2010) studies the optimal compensation mix of stock and bonuses in a dynamic model where managers can hide the true profitability of the firm and maximize their own revenue from equity portfolio holdings; they show that while executives' stock-based compensation may increase the alignment of managers' and shareholders' objectives, it may also induce the managers to misreport the true state of the firm and concentrate on short run, rather than long run, objectives.

\footnotetext{
${ }^{1}$ Giannetti and Metzger (2013) find that the increase in equity-based compensation and the consequent increase in the total compensation is related to greater competition for talents that creates retention motives and exacerbates agency problems in the allocation of effort.
} 
Our objective is to investigate how the risk-shifting problem between shareholders and debt-holders depends upon the adoption of compensation schemes tied to firm performance and their interaction with financial regulation (such as deposit insurance or capital regulation), rather than solving for the optimal compensation scheme in a dynamic environment.

Secondly, we aim to contribute to the empirical literature on the role of corporate governance on risk in banks. In particular, the recent paper by Ellul and Yeramilli (2013) provides a first attempt to open the black-box of the internal organization of a bank by studying the impact of heterogeneity in risk management functions on banks' risk in the US. We complement their analysis by studying the effect of CEO compensation schemes and the (potential) relative conflict with other stakeholders. Moreover, we build upon Laeven and Levine (2009) who empirically analyze the interaction between corporate governance and regulation and its effect on bank risk taking. Our findings complements their work by exploring a specific tool of corporate governance, that is managerial compensation.

Finally we contribute to the recent empirical evidence about the performance of commercial banks in the recent financial crisis. On this ground, Fahlenbrach and Stulz (2011) have empirically explored the relation between CEO incentives and bank performance in the 2007-2008 financial crisis using a cross-section of US banks. They find that banks whose CEOs' incentives were better aligned with shareholders' interests did not perform better other banks. They analyze the effects of different components of remuneration packages such as stock options or cash bonuses and conclude that none of them can explain the negative realizations of US bank returns during the downturn. Moreover, in a cross-country analysis, Beltratti and Stulz (2012) show that shareholder friendly boards have effectively aligned bank managers to their interests at the expense of depositors in the recent financial crisis. We complement those studies by looking explicitly at executives' monetary incentives in a cross-country analysis.

The aim of our theoretical contribution is to provide testable predictions together with a guidance for the empirical evidence. The model builds upon Cerasi and Daltung (2007) in its version for banks developed in Cerasi and Rochet (2014). In details, we present a model where banks lend to opaque entrepreneurial projects to be mon- 
itored by managers, but whose effort is not observable by outsiders; the manager might affect, through project monitoring, the amount of loan losses and is remunerated with a bonus related to the performance of the bank portfolio. Depositors are insured and there is capital regulation in place. This simple way of modeling the managerial compensation structure reflects, in a stylized way, the objective of payfor-performance schemes, that is to align shareholders and managerial interests. In the model, shareholders may monitor the manager through direct inspection and in some cases replace him with an outside manager. In a mixed strategy equilibrium, we show that the overall effect of a larger bonus on bank risk taking is ambiguous: on the one side, the higher the bonus, the higher the monitoring effort of the manager and the lower the risk taking; on the other side, a higher bonus discourages shareholders' supervision by reducing the stake of their return and leads to greater risk taking. The sign of the relation between the bonus and risk taking is ceteris paribus (for a given capital structure and regulatory environment) decreasing in the efficiency of shareholders' supervision. In other words, the effect of the bonus on risk taking is positive with weak monitoring by shareholders. Within this framework, we find that a risk-sensitive deposit insurance premium, by incorporating the expected increase in risk of a larger bonus, might, under certain conditions, weakens shareholder's supervision. In such a case, the positive relation between the bonus and risk taking is exacerbated.

In the empirical analysis we measure the effect of an increase in the variable part of managerial compensation of bank CEOs in 2006 on the performance and risk of banks around the World in the subsequent years, when the financial crisis occurred. The idea is to test whether managerial contracts and the consequent risk taking of CEOs before the financial crisis could have caused low performances and greater realized risk in banks during the 2007-2008 financial crisis. There are two main reasons why using the years around the great recession to this aim. First of all, risk taking shaped by the managerial compensation seems one of the main culprits in the public debate. However, as a matter of fact, Fahlenbrach and Stulz (2011) provide evidence that the greater alignment of bank CEO compensation in 2006 to the stock value was not related to lower stock returns during the years of the financial crisis in US. We apply a similar empirical strategy although on a novel cross-country sample of banks. 
Secondly, we assume that CEO compensation was not designed by shareholders in the years before the financial crisis anticipating the collapse. The financial crisis can be hardly classified as an anticipated shock given that both financial markets operators and managers were possibly unaware in 2006 of the upcoming crisis in mid2007. Coherently we find that average banks' stock returns in 2006 were positive and extremely high; ${ }^{2}$ in addition, we do not find in our sample a statistically significant change in the share of inside ownership by CEOs when comparing the second quarter of 2005 and 2006 to the second quarter of $2007 .^{3}$

Accordingly, in the empirical analysis we relate performance variables measured post-crisis (2007-2008) on lagged pre-crisis (2006) compensation variables. Pay-forperformance sensitivity of CEOs variable compensation has been measured by employing data on cash bonus and equity portfolios of CEOs. In particular we disentangle the contribution given by direct ownership of shares and stock options on one side, and cash bonuses on the other side; the reason is that these elements may give different incentives to focus on longer vs. shorter run outcomes (Benmelech et al. (2010)). For the stock options, following Core and Guay (2002) approximation, we distinguish between the sensitivity of CEOs' stock option portfolios to share prices (option delta) and the sensitivity to volatility of stocks (option vega). ${ }^{4}$ The reason for using these two measures is that Guay (1999) finds that firms equity risk is positively related to the convexity of the monetary incentives provided to CEOs; in particular Coles et al. (2006) find that the stock return volatility of risky investments is positively affected by the deltas and vegas calculated on managers' options. Bank performance is measured through buy and hold returns and standard deviation of stock returns over the period 2007:III-2008:IV.

Together with Suntheim (2010), this is one of the first papers to provide evidence in a cross-country sample. The lack of cross-country evidence in the literature is pri-

\footnotetext{
${ }^{2}$ Furthermore in the regression analysis we show that there is a negative relation between stock returns in 2006 and performance during the crisis; this result suggests that better performing banks in 2006, had the worse performance during the financial crisis.

${ }^{3}$ Insider holding has been measured by the ratio between the number of restricted and unrestricted shares held by CEOs at the end of the second quarter of each year and total number of shares at the end of the year. The average insider holding has been $1.41 \%, 1.76 \%$ and $1.38 \%$ respectively at the end of the second quarter of 2005, 2006 and 2007. There is not a statistically significant change also after excluding restricted shares. A similar evidence has been found by Fahlenbrach and Stulz (2011) for US banks

${ }^{4}$ See Appendix B for a definition of option delta and vega and how they have been calculated.
} 
marly due to the difficulties in gathering data on CEOs compensation and link it to accounting data at bank level and financial regulation at country level. For our purpose, we combine four sources of data: Capital IQ - People Intelligence, Bankscope, Datastream and the third wave of the Survey on Bank Regulation and Supervision by the World Bank. ${ }^{5}$

On the overall sample, we do not find that higher-pay-for performance sensitivity measured at the end of 2006 was related to worse stock return or higher volatility during the financial crisis. This negative result confirms the empirical finding by Fahlenbrach and Stulz (2011) for a different sample of banks. However, exploiting the theoretical predictions derived from our model, we exploit bank level heterogeneity and cross-country differences, to split the sample according to different dimensions (in terms of bank governance and regulation) and challenge the evidence on the overall sample.

In particular, we find that CEOs' equity incentives are related to worse performance during the financial crisis in banks where the efficiency, and consequently the intensity, of supervision by shareholders on delegated managers' activity was relatively low compared to the whole sample. By using different proxies for efficiency of supervision both at bank and country level, we support the theoretical prediction that weaker internal supervision, combined with higher pay-for-performance sensitivity in CEOs compensation schemes, might explain greater risk-taking in banks.

We furthermore study the interaction between CEOs' variable compensation and measures of prudential regulation at country level such as the presence of an explicit deposit insurance scheme ${ }^{6}$ and the level of capital requirements ${ }^{7}$.

The empirical evidence suggests that explicit deposit insurance, combined with

\footnotetext{
${ }^{5}$ See section 3 for a detailed description of the data

${ }^{6}$ Following Demirguc-Kunt et al. (2005) explicit deposit insurance differs from implicit deposit insurance by the reliance on a formal definition in national banking laws; explicit deposit insurance vary among countries by the application to different types of financial institutions and by the amount of coverage. In this paper we divide the countries into two groups if an explicit law applies or not to commercial banks; we furthermore assume that the insurance is funded with a fair premium paid by the commercial bank. Although restrictive, this assumption seems to fit the application of this law by the majority of countries.

${ }^{7}$ As a proxy for capital requirements we employ the Tier 1 capital adequacy ratio. Given that the level of Tier 1 in banks may also result from the influence of the financial authority in a country, we divide banks in our sample into two groups of high capitalized and low capitalized banks, under the assumption that those two groups belong to countries that feature respectively stricter and softer capital requirements.
} 
variable compensation schemes, increased the risk attitude of insiders and gave rise to worse performance (measured as either buy and hold returns or stock return volatility) during the financial crisis. As for capital requirements, we find evidence that variable compensation is indeed related to higher volatility during the financial crisis, but only for poorly capitalized banks.

The rest of the paper is organized as follows: section 2 presents our model; section 3 describes how we collected our dataset and provides some descriptive statistics of our sample of banks and their CEO's compensation; section 4 analyzes the relation between bank performance in the financial crisis and CEO compensation in the whole sample; section 5 studies the interaction between CEO incentives and financial regulation; and finally section 6 concludes.

\section{The model}

Consider a bank holding a portfolio of size $L_{0}$ of correlated loans. Each loan returns $R>1$, although loan losses $\ell$ may occur with probability $p$. Thus the portfolio returns $(R-\ell) L_{0}$ with probability $p$, and $R L_{0}$ otherwise: these returns are fully observable by third parties. The banker collects funds from wealthy dispersed investors whose alternative return on their capital is 1 . We assume that all agents are risk neutral. At date 0 the banker, with capital $E_{0}$, collects deposits $D_{0}$ and extends loans $L_{0}$. Loans can be monitored with intensity $m \in[0,1]$ in order to reduce the probability of losses from $p_{H}$ to $p_{L}$ with $\Delta \equiv p_{H}-p_{L}>0$. This effort has a private cost of $\frac{M}{2} m^{2}$ with $M \geq 0$.

The probability of incurring loan losses $\ell$, conditional on the monitoring effort, is:

$$
p(m)=p_{H}-m \Delta
$$

Assume that

$$
R-p_{L} \ell-\frac{M}{2}>1>R-p_{H} \ell
$$

which implies that only monitored loans are worth financing. Given that the monitoring effort is non-observable by third parties, but it affects the expected revenue of the portfolio of loans and it costs privately to whoever is in charge of monitoring inside the bank, there is moral hazard between depositors and bank insiders. To begin (basic model) we assume that the banker himself is in charge of monitoring the 
portfolio of loans. In the second part of this section we let the banker to delegate the task of monitoring the portfolio of loans to a manager. The basic model captures the case where the interests of the manager are completely aligned to those of his banker, while in the second they are not. We will refer to the first model when considering the case of insider ownership by the managers.

\subsection{A basic model (without managers)}

Consider three dates $t=(0,1,2)$ where we assume the following timing of events:

- at $t=0$ : the banker with capital $E_{0}$ collects deposits $D_{0}$ and lends $L_{0}$;

- at $t=1$ : the banker might exert a monitoring effort with intensity $m$ to reduce the size of expected loan losses;

- at $t=2$ : when the loans portfolio returns a revenue, its income is splitted among the parties.

We assume that depositors are fully insured, hence each unit of deposit bears zero risk premium. The game is solved backwards, starting from the choice of the optimal monitoring intensity at date 1 . Given the presence of the deposit insurance the income of the loans portfolio is divided according to the following scheme: when the portfolio returns $R L_{0}$ the income goes to the banker once depositors are repaid the promised amount $D_{0}$; when loan losses occur and the portfolio returns $(R-\ell) L_{0}<D_{0}$, all the income goes to the deposit insurance fund that repays depositors $D_{0}$, while it leaves the banker without any income. We will assume from now on that the deposit insurance premium is fully funded by the government. ${ }^{8}$

The banker's profit is

$$
U^{B}(m)=[1-p(m)]\left(R L_{0}-D_{0}\right)-\frac{M}{2} m^{2} L_{0}
$$

where the probability $p(m)$ is defined in (1).

\footnotetext{
${ }^{8}$ We will discuss the case of a risk-sensitive deposit insurance in the last subsection of the theoretical model where we assume that the banker has to pay an ex-ante fair premium levied at date 0 .
} 
We find the optimal choice of monitoring intensity $m$ by the banker at date 1 by solving the following first order condition:

$$
\frac{\partial U^{B}}{\partial m}=\Delta\left[R-\frac{D_{0}}{L_{0}}\right]-m M=0,
$$

given $D_{0}$ and $L_{0}$ set at date 0 . The amount of deposits that the banker will be able to collect is given by the bank's balance sheet at time 0 , i.e.

$$
L_{0}=E_{0}+D_{0}
$$

We will assume in what follows that there is a capital ratio $k$ imposed by the regulator requiring a minimum of capital for each unit of loans, namely $L_{0} \leq E_{0} / k$. When loans are monitored, they have a positive NPV by assumption (2), hence the size of the bank is limited by this minimum capital ratio.

We can now derive the solution of the model:

Proposition 1 When the optimal lending size is limited by a capital ratio $k$ such that $L_{0} \leq E_{0} / k$ and there is a flat deposit insurance funded with public money, the monitoring intensity $\widehat{m}$ and the probability of loan losses $\widehat{p}$ are the solution to the following system of equations:

$$
\begin{aligned}
(1-k)-R+\frac{M}{\Delta} \widehat{m} & =0, \\
\widehat{p}-p_{H}+\widehat{m} \Delta & =0 .
\end{aligned}
$$

Proof. Assume that the NPV of each is greater than 1, otherwise the bank is not viable. This implies that the size of the bank is limited by the capital ratio $k$.Substituting the amount of deposits from (5) into (4), we derive equation (6). Adding the definition of probability in (1), we derive the system of equations (6)-(7) which determines the equilibrium values $(\widehat{m}, \widehat{p})$.

According to eq. (7) the greater the monitoring effort the smaller the probability of incurring in losses on the portafolio of loans. The factors affecting the probability of loan losses are listed in equation (6) and they are the capital ratio $k$, the size of loan losses $\ell$, the cost of monitoring $M$ and the ex-post return on loans $R$. 
To understand the impact of such factors on the risk-taking incentives, measured by the probability of loan losses $\widehat{p}$, we can perform few easy comparative static exercises around the equilibrium values $(\widehat{p}, \widehat{m})$. In particular it is possible to show the following result:

Proposition 2 The ex-ante probability of loan losses $\hat{p}$ increases with smaller expost return of the portfolio of loans $R$ and with a lower capital ratio $k$ and higher monitoring costs $M$.

Proof. By substituing (7) into (6) we derive the equilibrium probability of loan losses

$$
\widehat{p}=p_{H}-\frac{\Delta^{2}}{M}[R-(1-k)]
$$

from which all the results of our comparative static exercise follow.

A higher capital ratio $k$ reduces the probability of loan losses. The reason is the following: a larger capital requirement reduces the amount of deposits needed to fund a given portfolio of loans, and therefore it increases the marginal revenue accruing to the banker for his effort according to equation (4). This improves his incentive to exert monitoring and thus reduces the probability of loan losses. A larger ex-post return $R$ or a lower monitoring cost $M$ increase directly the marginal revenue that accrues to the banker affecting his incentive to exert effort and reduces the probability of loans losses.

\subsection{The model with managers}

We now assume that the banker delegates the task of monitoring loans to a manager. Since the banker cannot observe the monitoring intensity exerted by the manager, now the moral hazard problem is not only between outsiders (depositors) and insiders (banker and manager) but also inside the bank between the manager and the banker. To control the moral hazard inside the bank the banker (assumed to be the unique active shareholder of the bank) can not only inspect his manager but also reward him with monetary incentives.

It is in fact the manager now who exerts the monitoring effort $m \in[0,1]$ at the private cost $\frac{M}{2} m^{2}$ with $M \geq 0$. Given that monitoring has a private cost but it is not observable, the manager might shirk. To avoid this the banker can on one hand 
inspect the manager at random, but on the other hand reward him through monetary incentives whenever he observes high returns on the portfolio of loans. We have in mind a pay-for-performance scheme. We postpone the analysis of monetary incentives to the next sub-section, while we focus now on the inspection technology. The banker might inspect the activity of the manager with intensity $s \in[0,1]$. Inspecting his manager with intensity $s$, translates into a probability $s$ of observing the true managerial effort, but it costs (privately) $\frac{C}{2} s^{2}$ with $C>0$. As a result of his inspection, the banker might decide to fire the manager and replace him with an external one (we explore this aspect later on).

The two costly efforts, "internal" supervision and monitoring of loans, cannot be observed outside the bank: given that the banker cannot observe the behavior of the manager without costs and depositors cannot observe neither of the two efforts, a double moral hazard is present in the model. However the combined impact of the monitoring by the manager and internal supervision by the banker affect the probability of losses $p \in\left[p_{L}, p_{H}\right]$ with $\Delta \equiv p_{H}-p_{L}>0$. The specific form of the probability is endogenous and must be derived from the combination of effort choices of the manager and the banker, as it will become clear in a while.

The timing of the model is as follows:

- at $t=0$ : the banker with capital $E_{0}$ collects deposits $D_{0}$ and lends $L_{0}$ (limited by capital requirement $\left.L_{0} \leq E_{0} / k\right)$ and hires a manager to monitor loans;

- at $t=1$ : the manager might exert a monitoring effort with intensity $m$ to reduce expected loan losses; the banker inspects him with probability $s$; in some cases he might decide to replace the incumbent manager with an external one;

- at $t=2$ : the loans portfolio returns a revenue and the income is shared among the parties.

At the beginning of date 0 , the banker sets the managerial compensation for his manager. Effort choices are not observable, while returns from projects are observable to outsiders. With this timing we assume that outsiders can observe only the managerial compensation but cannot infer the true effort choices of insiders. The model is solved backwards: equilibrium efforts and returns are computed for given managerial compensation. 


\subsubsection{Managerial compensation}

The manager, whose choice of effort responds to monetary incentives, is offered a managerial compensation, sum of a fixed salary and a bonus on each loan. The fixed salary is set for simplicity equal to zero. In addition the manager is paid $b \in[0, R)$ conditionally on the fully observable return of the bank portfolio, i.e. the manager pockets the bonus whenever the loan portfolio succeeds without losses and the banker - as a result of an inspection - decides not to fire him. ${ }^{9}$ The bonus represents the variable part of the managerial compensation. Only conditional on the result of an inspection the banker might decide to fire the incumbent manager. Whenever the incumbent manager is fired, a new external manager is hired and, as a result, the probability of loan losses switches from $p$ to an average value $\phi \in\left(p_{L}, p_{H}\right)$. Since the new manager is offered the same managerial compensation as the incumbent one, ${ }^{10}$ the banker benefits from firing the incumbent manager only when - as a result of his inspection - he observes an effort level below that of an average external manager. Otherwise he strictly prefers to retain his incumbent manager in order to reduce loan losses. In conclusion, the banker will not fire the incumbent manager unless he has inspected him, i.e. $s>0$, and he will not fire him unless he observes an effort level below that of an external manager.

The banker and the manager choose their efforts non-cooperatively and simultaneously. Figure 1 depicts the strategic interaction of the banker and the incumbent manager as well as the variables affecting their gross incomes, for given effort choices.

From Figure 1 we can derive the probability of loan losses when monitoring is delegated to a manager taking into account all possible cases:

$$
p(m, s)=p_{H}-m \Delta-s(1-m) \Delta_{\phi}
$$

where $\Delta \equiv p_{H}-p_{L}$ and $\Delta_{\phi} \equiv p_{H}-\phi$. The probability of losses is $p_{H}$ when both manager or banker shirk; this probability can be reduced by whoever exerts some effort.

\footnotetext{
${ }^{9}$ The decision to fire the manager is at the banker's discretion. This is in line with the empirical fact that managerial contracts are riskier when compared to workers' labor contracts. In particular in the managerial contract there is no need of a "good cause" to fire the employee.

${ }^{10}$ This assumption guarantees that the banker does not always fire the incumbent manager disregarding the outcome of the inspection, given that the managerial effort is not observable from outsiders. After firing a manager, the banker hires an external manager and pays him exactly the same bonus: thus the reason to fire the old manager cannot be to save the bonus.
} 
Figure 1: decision tree for banker and manager

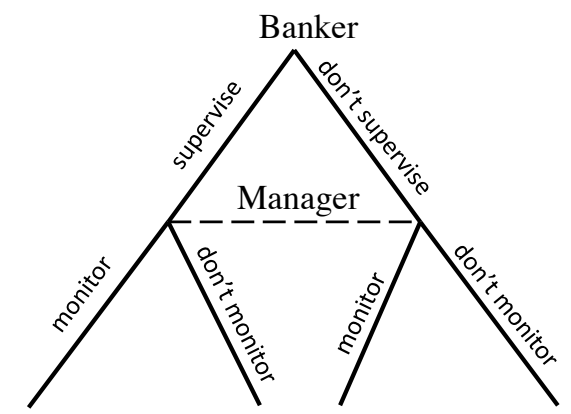
Banker:
$\left(p_{L} ;-b\right)$
$(\phi ;-b)\left(p_{L} ;-b\right)$
$\left(p_{H} ;-b\right)$
Manager (incumbent):
b
0
b
b

\begin{abstract}
Fig 1. The decision tree represents all the possible actions for the banker and the incumbent manager.. Each branch represents the decision about the action of monitoring and internal supervision. At the bottom of the tree we report the specific values resulting as outcome of the variables affecting the payoff of each player. For instance in the first branch, both the banker supervises and the manager monitors, hence the probability of incurring in loan losses is $\mathrm{p}_{\mathrm{L}}$ and, conditional on zero loan losses, the banker rewards the manager with the bonus $\mathrm{b}$.
\end{abstract}

Notice that internal supervision by the banker is effective in reducing the probability of losses only if, once shirking is detected, the banker replaces the incumbent manager with a more efficient one. This benefit is larger the greater the probability of shirking and the higher the ability of external managers, $\phi>p_{L}$.

For given managerial compensation, the expected utility of the incumbent manager is

$$
U^{M}(m, s)=[1-q(m, s)] b L_{0}-\frac{M}{2} m^{2} L_{0},
$$

where $1-q(m, s) \equiv 1-p(m, s)-s(1-m)(1-\phi)$ is the probability that the manager is rewarded the bonus. When the manager exerts effort with probability $m$, he earns the managerial bonus with probability $\left(1-p_{L}\right)$; if he shirks his duties and the banker does not detect him, this occurs with probability $(1-m)(1-s)$, he might still earn the managerial bonus whenever there are no losses on the portfolio with probability $\left(1-p_{H}\right)$; finally he is not paid the bonus when fired with probability $s(1-m)$. Notice 
that the probability of losing the bonus for the incumbent manager is larger compared to the probability of loan losses, that is $p(m, s)-q(m, s)=-s(1-m)(1-\phi)<0$. The portfolio of loans might still be successful due to the new manager's effort; in this case the incumbent manager does not pocket the bonus, because he is fired, however the bonus is rewarded conditional on loan portfolio success to the new manager.

The optimal choice of monitoring intensity $m$ by the manager at date 1 , is given by the solution to the following first order condition

$$
\frac{\partial U^{M}}{\partial m}=\left[\Delta+s\left(1-p_{H}\right)\right] b-M m=0
$$

given the inspection probability $s$ and the managerial bonus $b$. Eq.(10) shows that, for a given bonus, the monitoring effort of the manager improves with a greater internal supervision by the main shareholder: greater supervision by the banker (larger probability of inspection) increases the threat of being fired when shirking is observed, inducing a greater managerial effort.

\subsubsection{Equilibrium bank risk}

The banker with capital $E_{0}$ collects deposits $D_{0}$ and extend $L_{0}$ loans subject to the upper limit given by the capital requirement $k$. Depositors will be repaid a face value $D_{0}$ in date 2. Given that the banker is subject to limited liability, in case the loan portfolio falls shorter due to losses, the deposit insurance (fully funded by public money) repays depositors the entire face value $D_{0}$. As before, the model is closed by the balance sheet constraint at date 0 given by equation (5).

The expected profit of the banker (the main shareholder of the bank) can be expressed as

$$
U^{B}(m, s)=[1-p(m, s)]\left[(R-b) L_{0}-D_{0}\right]-\frac{C}{2} s^{2} L_{0}
$$

where the probability $p(m, s)$ is defined in (8), the first term represents the expected total return of the bank portfolio net of managerial bonus and repayment to depositors and the second term is the banker's supervisory cost.

The optimal choice of internal supervision intensity $s$ by the banker at date 1 , is given by the solution to the following first order condition

$$
\frac{\partial U^{B}}{\partial s}=(1-m) \Delta_{\phi}\left[(R-b)-\frac{D_{0}}{L_{0}}\right]-C s=0,
$$


where the managerial effort $m$, the amount of deposits $D_{0}$, size of the loan portfolio $L_{0}$ and managerial bonus $b$ are taken as given at this stage.

Eq.(12) shows that, for a given bonus and amount of deposits, the benefit of internal supervision depends negatively upon the managerial effort due to a freeriding problem: a greater managerial effort improves the probability of success of the project without costs for the banker, while inspection entails a positive private cost. The banker prefers the manager to exert the effort to save his private cost of supervision. Hence there is substitutability between the two efforts.

The banker and the manager choose simultaneously and non-cooperatively their efforts. We characterize the equilibrium of the game in the following Proposition:

Proposition 3 When the optimal lending size is limited by the capital ratio $k$ such that $L_{0} \leq E_{0} / k$ and there is a flat deposit insurance funded with public money, the monitoring intensity $\widehat{m}$ of the manager, the internal supervision of the banker $\widehat{s}$ and the probability of loan losses $\widehat{p}$ are the solution to the following system of equations:

$$
\begin{array}{r}
(1-k)-R+b+\widehat{\Omega}=0 \\
{\left[\Delta+\widehat{s}\left(1-p_{H}\right)\right] b-\widehat{m} M=0} \\
\widehat{p}-p_{H}+\widehat{m} \Delta+\widehat{s}(1-\widehat{m}) \Delta_{\phi}=0
\end{array}
$$

with $\widehat{\Omega} \equiv \frac{C \widehat{s}}{(1-\widehat{m}) \Delta_{\phi}}$.

Proof. See in Appendix A.

As in the basic model we can study the impact of the exogenous factors such as a larger capital ratio $k$, or measures of ex-post profitability such as $R$ and effort costs $C$ and $M$ on the riskiness of the bank. We can as a matter of fact capture with the probability of loan losses $\widehat{p}$ either a measure of the variance of the loan portfolio returns or a measure of loans performance. ${ }^{11}$

\footnotetext{
${ }^{11}$ In the model when the manager or the shareholder exerts a greater effort in monitoring the loan portfolio risk, $p$ decreases. This corresponds either to an increase in the mean value of the portfolio, $R(1-p)$, or a reduction of the variance, $R p(1-p)$, when $p$ is smaller than 0.5 , which seems a sensible restriction to adopt when loan losses are rare. However our ex-ante measure of risk $p$ cannot be observed and we must capture it with observable measures. In the empirical analysis our ex-ante measure of risk $p$ is approximated either with a measure of performance of the loan portfolio, that is buy and hold return, or with a measure of ex-post volatility, standard deviation of stock returns
} 
When we approximate bank risk by the ex-ante probability of loan losses $\widehat{p}$, we can therefore perform some comparative static exercises around the equilibrium values $(\widehat{p}, \widehat{s}, \widehat{m})$. In particular it is possible to show the following results:

Proposition 4 The probability of loan losses $\widehat{p}$ decreases with a larger capital ratio $k$ and with a smaller inspection cost by shareholders $C$.

Proof. See in Appendix A.

The model predicts that a larger capital ratio reduces the ex-ante riskiness of the bank. The intuition is the following: a larger capital ratio, larger $k$, reduces the need for external funds from depositors, for a given size of the bank $L_{0}$. This increases the marginal revenue of shareholders and improves their incentives to inspect the manager. This has a positive effect on managerial monitoring and on the overall expected return of portfolio of loans. With the same logic, a smaller inspection cost by shareholders, lower $C$, causes the opposite effect by decreasing the marginal cost of internal supervision. In the empirical analysis we measure both effects exploiting the cross-country variation in our sample. On one side we measure the effect of different capital ratios and on the other side we compare regulatory systems where different intensities of external supervision reduce the cost of internal supervision.

Finally within our model we can study the effect of a larger bonus on the risk of the bank.

Proposition 5 A larger bonus b has a negative effect on the intensity of supervision $\widehat{s}$ of the banker, while it might improve the monitoring effort $\widehat{m}$ of the manager. Overall a larger bonus has an ambiguous effect on the probability of loan losses $\widehat{p}$.

Proof. See in Appendix A.

The ambiguity of the sign on bank risk is due to the complex interaction of monetary incentives set to reward the manager with the banker's incentive to exert an effort that might reduce the overall bank risk. As a matter of fact the efforts of the two insiders, banker and manager, are substitutable: a larger monetary incentive to the manager discourages in part the banker from exerting his supervision, who might then be tempted to free-ride on the effort of the manager, and this has an impact on the overall bank risk. 
The reason is that a larger bonus reduces the marginal benefit of the banker. The stake of profits retained by the banker when he pays a larger bonus to his manager is smaller (direct effect through $b$ ) and his inspection is less effective if the manager behaves (indirect effect through $(1-m)$ ), thus in equation (12) ceteris paribus the marginal benefit of inspection is reduced. The overall effect on the equilibrium probability of loan losses $\widehat{p}$ is the result of the two opposite forces: an increased managerial effort due to the monetary incentive of the bonus and a reduced internal supervision by the banker. This explains the ambiguity of the overall effect on the measure of riskiness when increasing the managerial bonus.

It is possible to give a graphical representation of the equilibrium efforts in the mixed strategy Nash equilibrium.

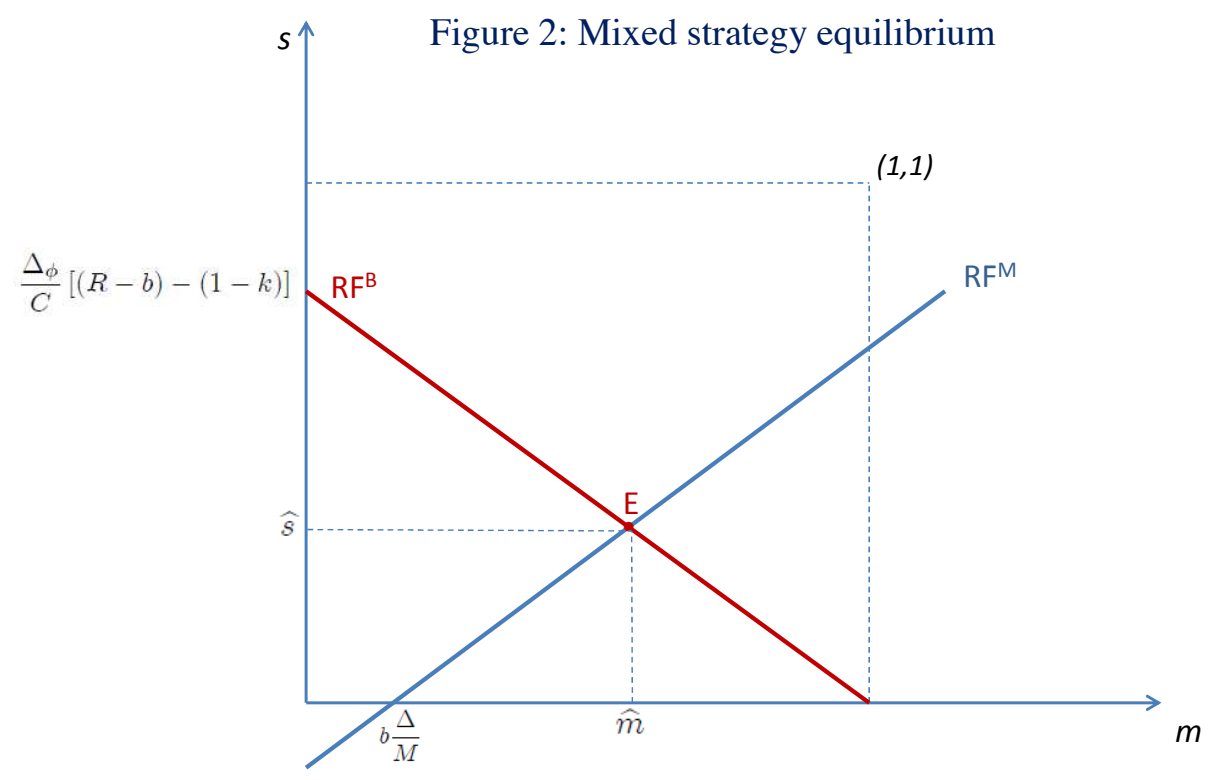

Fig 2. The diagram represents the two reaction functions, the one negatively sloped is the reaction function of the banker $\mathrm{RF}^{\mathrm{B}}$, while that positively sloped is the reaction function of the manager $\mathrm{RF}^{\mathrm{M}}$. From the mixed strategy equilibrium, represented by the intersection of the two linear reaction functions in $\mathrm{E}$, we derive the equilibrium effort levels.

In the diagram we represent the equilibrium efforts as the couple $(\widehat{s}, \widehat{m})$ at the intersection of the two reaction functions. We can perform graphically the comparative 
static exercise that results from a change in $b$ in Proposition 5 by simply shifting the reaction functions.

Figure 3: Increase in the managerial bonus b

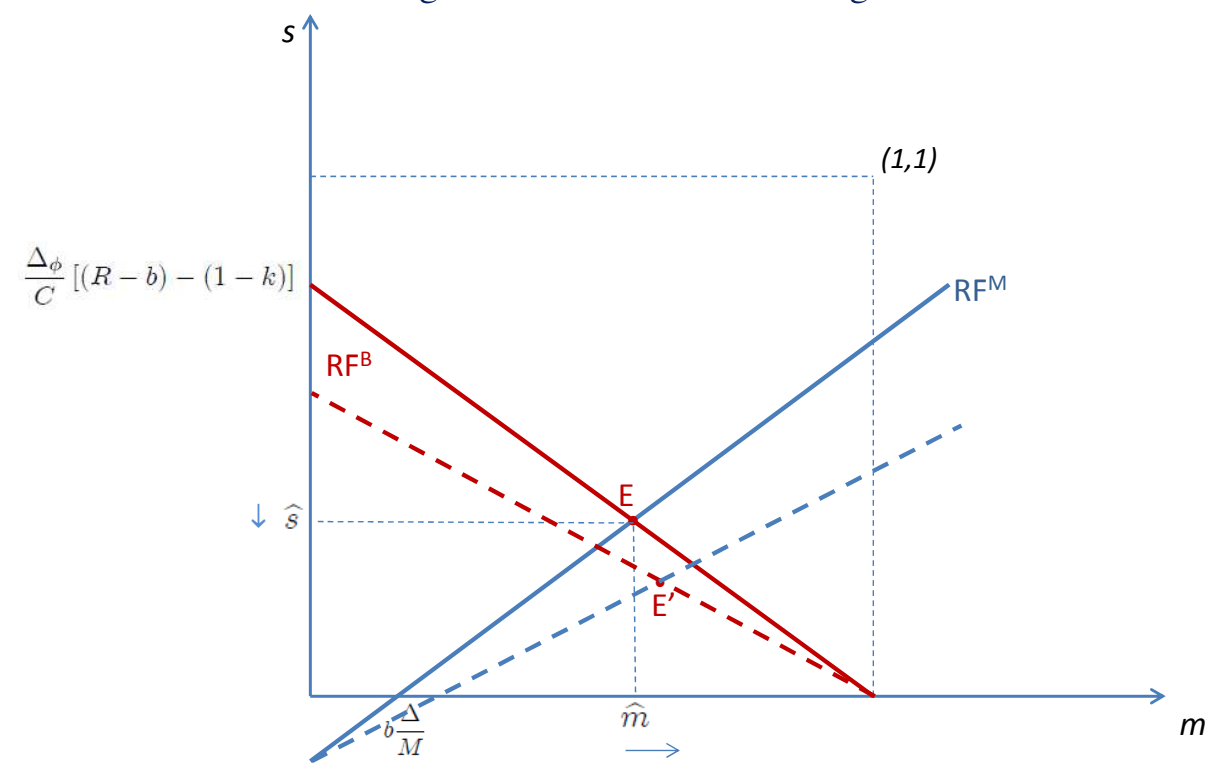

Fig 3. The diagram represents the effect of an increase in the bonus b on the equilibrium effort levels. While it is evident that the supervision effort decreases, the effect on the managerial effort is less sharpe. The reason is that an increase in the bonus has a direct effect on the managerial effort due to a larger rewards, but it reduces also the internal supervision increasing the threat of firing the incumbent manager due to a subsitution effect. Overall the sing of the effect is ambiguous.

Proposition 5 shows that the outcome is ambiguous due to the uncertain impact on managerial effort. While on the one hand the bonus increases the monetary reward for the manager who behaves, on the other hand it decreases the internal supervision, inducing greater shirking. The net effect is therefore uncertain.

The ambiguity of this last result calls for an empirical exploration of the impact of a larger bonus on bank risk.

\subsubsection{Risk-sensitive deposit insurance}

We now relax the assumption of a flat deposit insurance funded with public money. When the deposit insurance premium is levied on the banker at date 0 , there is an additional countervailing effect due to the effect on the riskiness of the loan portfolio. 
Assume that the banker pays a fair premium at date 0 in order to fund the (fully private) deposit insurance, that is covering the difference between the return on the loans in case of loan losses and the face value of deposits, i.e.:

$$
\pi_{0}=p(m, s)\left[D_{0}-(R-\ell) L_{0}\right]
$$

Now the bank's balance sheet constraint at date 0 is given by the following equation

$$
E_{0}+D_{0}=\pi_{0}+L_{0}
$$

All the rest of the model is unchanged. Now the equilibrium is the following:

Proposition 6 When the optimal lending size is limited by the capital ratio $k$ such that $L_{0} \leq E_{0} / k$ and the deposit insurance premium is fair, the monitoring intensity $\widetilde{m}$ of the manager, the supervisory effort of the banker $\widetilde{s}$ and the probability of loan losses $\widetilde{p}$ are the solution to the following system of equations:

$$
\begin{aligned}
(1-k)-(R-\widetilde{p} \ell)+(1-\widetilde{p})[b+\widetilde{\Omega}] & =0 \\
{\left[\Delta+\widetilde{s}\left(1-p_{H}\right)\right] b-\widetilde{m} M } & =0 \\
\widetilde{p}-p_{H}+\widetilde{m} \Delta+\widetilde{s}(1-\widetilde{m}) \Delta_{\phi} & =0
\end{aligned}
$$

with $\widetilde{\Omega} \equiv \frac{C \widetilde{s}}{(1-\widetilde{m}) \Delta_{\phi}}$.

Proof. Assume that conditions (10) and (12) are binding; after substituting the fair premium (16) into (17) we derive the equations (18) and (19). Adding the definition of probability (20), we derive the system of equations (18)-(20) which determines the equilibrium values $(\widetilde{p}, \widetilde{s}, \widetilde{m})$. Notice that this system is non-linear and therefore cannot be solved explicitly.

The effect of a change of the bonus on the probability of loan losses is based on the result in Proposition 7 in the Appendix. When the overall effect of a larger bonus is positive, a risk sensitive deposit insurance premium changes reflecting a lower riskiness, therefore the stake of profits retained by the banker increases, improving the marginal benefit of supervision. This initiates a virtuous circle by which the negative effect on the supervision of the banker is reduced. Hence an increase in managerial bonus can be more effective. However when the effect of an increased bonus causes an increase in risk, a risk-sensitive deposit insurance premium might exacerbate the 
negative effect: a risk-sensitive premium reacts to the increase in risk, by reducing the retained stake of profits for the banker and this creates a further disincentive to his supervision. The overall negative effect on risk might be even larger with a risk-sensitive deposit insurance. This is why in the empirical analysis we measure the effect of larger managerial compensations by taking into account the cross-country heterogeneity derived from the different institutional arrangements concerning deposit insurance.

\section{Data sources}

This paper contributes to the empirical literature by building a new database from the matching of four different sources of data. The final goal is to obtain a panel of large banks from several countries around the World where each observation represents the specific Bank-CEO-Year-Country quadruple. In particular, we want to combine information at bank level (such as balance sheet) with information on compensation at CEO level, for different points in time and for different countries. One issue with building such a dataset is the difficulty in matching different sources absent direct linkages between databases. In order to link accounting and performance data with CEO compensation data, we merge observations from two different sources: Bankscope $^{12}$ and Capital IQ - People Intelligence. ${ }^{13}$ From Capital IQ we initially select all commercial banks, saving institutions (SIC codes: 6020, 6021, 6029, 6036) and bank holding companies (BHCs which SIC code is 6719) for which the compensation of CEOs is observed for at least one year over the period 2005-2009; from BHCs we exclude those banks whose primary specialization is brokerage and financial services (SIC codes 6162, 6199, 6200 and 6211). We then match this group of selected banks with the top ten largest publicly listed banks for each country as defined by their total assets. We select the top ten banks for each year from 2005 to 2009. This selection process allows us to include in the sample banks that eventually disappeared during the crisis because of mergers and acquisitions or default. The third match

\footnotetext{
${ }^{12} \mathrm{~A}$ directory and financial reporting service on 30,000 banks worldwide provided by Bureau van Dijk. It provides standardized reports, ratings, and ownership data as well as financial analysis functions.

${ }^{13} \mathrm{~A}$ database provided by Standard and Poor on the profiles of public and private firms worldwide including financials, officers and directors, ownership, advisory relationships, transactions, securities, key developments, estimates, key documents, credit ratings and filings.
} 
of data sources is with Datastream, from which we obtain information about stock returns and equity prices at daily and weekly frequency in the years from 2005 to 2009. Finally, to add financial regulation data at country level, we use indicators from Caprio et al. (2007) who exploits the third wave of the Survey on Bank Regulation and Supervision by the World Bank. ${ }^{14}$ We end up with a sample of 116 very large banks from 26 countries. $^{15}$ Not surprisingly, the majority of observed banks comes from countries where the disclosure of manager compensation is mandatory (US, for example). In the next section we will describe in details the sample of banks and their CEOs' compensation variables that are used in the empirical analysis.

\subsection{Descriptive statistics}

In the next two sub-sections, we provide summary statistics of our sample of banks and their CEOs' compensation variables. In particular, in the following sub-section, we examine accounting statements at the end of 2006 and later performance that is related to the period October 2007 - December 2008; in the subsequent sub-section we examine summary statistics of CEO compensations and equity ownership measured at the end of 2006. Notice that all variables have been reported in US dollar at the end of the year.

\subsubsection{Banks}

Table 2 shows the descriptive statistics for the selected sample of banks. We end up with a sample of 116 very large banks. The value of total assets is in fact significantly bigger compared to related papers that focus on a sample of US banks (Fahlenbrach and Stulz (2011)). Our sample is comparable to the sample used by Beltratti and Stulz (2012), although we have fewer observations because compensation variables are not available for all banks due to the lack of mandatory disclosure rules. While sample size may represent a limit for the external validity of the empirical analysis, focusing on largest banks has the advantage of enhancing their comparability. As argued by Laeven and Levine (2009), largest groups tend, in fact, to better comply with international accounting standards. The average and median book to market ratio smaller than one signals that banks were potentially growing in 2006 . This

\footnotetext{
${ }^{14} \mathrm{We}$ present a list and a detailed description of our variables of interest in Appendix B.

${ }^{15}$ We present the final list of banks and countries in Appendix C.
} 
evidence, combined with the positive average stock return between 2005 and 2006 of about $26 \%$, suggests that the huge drop in stock returns from 2007:III was, to some extent, still unexpected at the end of 2006. The average buy and hold return in the period 2007:III-2008:IV has been about -47\%; this underlines how deep has been the financial crisis for the banking sector worldwide. The Tier 1 capital ratio is not observed for all banks. We will include this variable as a control in our analysis given its importance for the evaluation of bank stability for supervision authorities though it is not observed in more than $10 \%$ of the observations in our sample. The mean value of Tier 1 capital ratio suggests that banks in 2006 were, on average, above the constraint of Basel II.

\section{Insert Table 2 here}

\subsubsection{CEO compensations}

Table 3 provides descriptive statistics of the compensation packages and the value of equity portfolios for the CEOs employed in 2006 by the banks of our sample. Panel A summarizes the various components of total compensation. While average annual compensation is about 3 million of dollars, the median value is about 1 million; this suggests that even within our sample of very big banks, there are fewer CEOs that are paid much more than others. Annual bonuses paid in cash are, on average 1.5 times the fixed salary. Moreover cash bonuses are more widespread as compensation tool than bonuses paid in equity (shares and/or stock options); the median value of equity bonuses is in fact zero, which implies that more than half of banks in our sample did not award any stock and/or option in 2006 to their CEOs. Panel B summarizes the equity portfolio of CEOs. Equity portfolio for each CEO is the sum of shares (restricted and unrestricted) and stock options accumulated till the end of 2006. The average value of equity portfolio is 35 millions. Median value of shares (restricted and unrestricted) was about 725.000 dollars at the end of 2006. We can see that direct holding of shares is more widespread than stock options holding. Panel C summarizes variables that will be used in the empirical analysis as they measure the sensibility to take risk for a given equity portfolio. The data on shares and options ownership shows, in fact, that a CEO would gain $1.5 \%$ of his total wealth for a $1 \%$ increase in share prices. Percentage equity risk (vega weighted for all options) tells that CEO 
would gain $0.7 \%$ of his stock-options wealth for a $1 \%$ increase in volatility of share prices.

\section{Insert Table 3 here}

\section{Financial crisis and CEO compensation}

In this section we analyze the relation between bank performance and risk in the financial crisis with CEO monetary incentives in the pre-crisis year. Following the structure and the predictions of the theoretical framework, the underlying assumption in the following empirical analysis is that shareholders were not expecting their bank's performance in the financial crisis when they set the compensation schemes in the years that preceded the collapse. Consequently, we run the the following OLS regression:

$$
Y_{i, 07-08}=\alpha+\beta V C_{i, 2006}+\gamma \text { Controls }_{i, 2006}+\epsilon_{i, 07-08}
$$

where the dependent variable $Y_{i, 07-08}$ is measured in terms of either buy and hold return of each bank stock price or standard deviation of stock returns in the period 2007:III - 2008:IV. We decided to exclude the first two quarters of $2009^{16}$ in the measures of these variables because bank returns in this last part of the recession may have been affected by national recovery policies. On the right hand side of equation (21), we capture CEO monetary incentives by using different measures of variable compensation in $2006 V C_{i, 2006}$. Following related literature on the effect of variable compensation on risk taking we consider separately measures of shorter term incentives given by annual cash compensation and measures of longer term incentives given by equity portfolio positions. Short term incentives are measured by cash bonus over fixed salary in 2006. Equity incentives are measured by shares and options holdings and by the percentage equity risk (vega) evaluated in 2006 . We will add control variables at bank level to measure capitalization, leverage and pre-crisis performance of banks in 2006.

\footnotetext{
${ }^{16}$ So, we do not conform to NBER dates of the Great Recession, namely 2007:III-2009:II
} 


\subsection{Stock return}

In this section we consider as dependent variable the buy and hold returns (BHR, hereafter) in the period 2007:III - 2008:IV. Table 4 summarizes the results.

\section{Insert Table 4 here}

In columns (1) to (3) we study the relation between the BHR of banks during the financial crisis and three different measures of the variable compensation component of CEO remuneration. In particular we separately employ measures of monetary incentives that make CEOs focusing on short run (cash bonus over fixed salary) and on long run outcomes (direct holding of shares and stock options); within this second category, following related literature in corporate finance (notably, Guay (1999)), we distinguish between the sensitivity of CEOs' equity portfolio to share prices (holdings of shares and options) and the sensitivity of CEOs' stock option portfolio to volatility of stocks (equity risk). At a first glance, we find no direct relation between each single component of the variable compensation and ex-post performance. In columns (4) to (6) we analyze the joint effects of the above three components also controlling for variables at bank level. In columns (4) we control for measures of performance between 2005 and 2006 (stock return), book to market ratio and market capitalization; in columns (5) we add a measure of leverage as additional control; in columns (6) we add the Tier 1 Regulatory Capital ratio, which is a measure of capital adequacy and liquidity. ${ }^{17}$ The results in columns (4) to (6) reveals that, while variable compensation has no direct impact on BHR in the financial crisis, banks with higher stock returns and book to market ratio in 2006, performed significantly worse than other banks; moreover, banks with higher Tier 1 performed relatively better. These results are in line with the results in Fahlenbrach and Stulz (2011) for a sample of US banks only; however, in the next empirical analysis we show that variable compensation affects indeed the performance of banks when we interact it with the institutional and regulatory context in which the bank is framed.

\footnotetext{
${ }^{17}$ While we acknowledge the importance of such variable for the performance of banks, we separately add it in the regression analysis as it is not observed for about $10 \%$ of companies in our sample.
} 


\subsection{Risk return}

In this section we replicate the previous analysis except that we analyze the effect of variable compensation on banks' risk return (the variance of stock returns, RR, hereafter). The reason is that the convexity of monetary returns may affect not only the return of investments but also its risk (Coles et al. (2006)). Results are in Table 5.

\section{Insert Table 5 here}

Results in columns (2) to (5) show that monetary incentives given by stock options significantly affect the realized volatility of banks' stock during the financial crisis. In particular, the holdings of shares and options and the equity risk affected the volatility of stock returns in two opposite directions. While the first has been related to a smaller volatility, the second has positively impacted on RR. However, the effect of these variables becomes weaker in terms of statistical significance in column (6), when we add the Tier 1 as additional control. This last result calls for a further exploration of the relation between capital requirements and variable compensation as we discuss in the next section.

\section{The effect of financial regulation}

The evidence provided in the previous section is in line with Proposition 5 of our model: variable compensation may have an ambiguous effect on risk-taking depending upon the incentives to monitor by managers and to supervise by shareholders, which ultimately depends upon the regulatory environment and relative efficiency in monitoring/supervisory activities; coherently, in our whole sample we find no direct effect of variable compensation on performance. Our interpretation is that the potential positive effects of variable compensation have been, to some extent, counterbalanced by the negative effects; as a result, we do not find a direct effect on risk taking. However, this result doesn't prevent the possibility that variable compensation may have significantly impacted on the performance of banks only under certain regulatory/institutional conditions. The scope of the next analysis is precisely to explore the interaction between regulation and variable compensation on ex-post performance, under the guidance of the insights of the theoretical section. In 
particular we present additional empirical analysis to address three main theoretical predictions: 1) weaker monitoring by shareholders (measured by different proxies), combined with variable compensation, might increase the risk-taking attitude of delegated managers; 2) when variable compensation has a negative effect on the risk of banks, a risk-sensitive deposit insurance premium might exacerbate its negative effect; for this reason we will exploit differences in the institutional arrangements related to deposit insurance at country level in our sample; 3) higher capital requirements may lead to lower risk taking by insiders, since a larger capital ratio increases the marginal revenues from bank activities. The following analysis does not only provide a support to our theoretical predictions, but also complements previous work in the literature that emphasizes the role of corporate governance and regulation for risk-taking in banks. It moreover sheds new light on the mechanisms that may induce CEOs to take excessive risks.

\subsection{The effect of shareholders' supervision}

In the current analysis, we want to study the effects of CEO monetary incentives in environments where the efficiency, and consequently the intensity, of supervision by shareholders on delegated managers is relatively higher compared to the whole sample. For this purpose, we identify proxies for the efficiency of supervision both at bank level and financial regulation level. Following seminal contributions in the corporate governance literature (Jensen and Meckling (1976) and Shleifer and Vishny (1986)) we firstly proxy the efficiency of supervision by ownership concentration in the bank. The main hypothesis is that dispersed shareholders have less power and incentives to shape corporate behavior due to the greater marginal cost they have in supervising compared to their benefit. We measure ownership concentration as the sum of the shares of the largest three shareholders (C3 index) and we examine how ownership structure interacts with variable compensation in shaping risk-taking behavior of individual banks. We split the sample into two subsamples, according to whether the value of the C3 index is below (greater cost of internal supervision by shareholders, due to share dispersion) or above the median, and ask if there is a significant difference in the average compensation schemes adopted in the two groups of banks. Evidence from table 6 shows that banks with less concentrated ownership 
were significantly bigger in terms of total assets (measured at the end of 2006) and awarded significantly larger bonuses (both in form of cash and equity) to their CEOs in 2006 .

\section{Insert Table 6 here}

To see if this difference in compensation structure have impacted on performance of banks during the financial crisis, we run a regression analysis similar to that in section 4 by splitting the original sample in the two sub-samples. Results are in Table 7.

\section{Insert Table 7 here}

Columns (1) and (2) replicates the regression analysis of the full specification in column (6) of tables 4 and 5 for the subsample of banks with lower ownership concentration. Notice that we have fewer observations in this analysis compared to table 6 as the inclusion of Tier 1 as regressor reduces the sample size. The analysis reveals that, in the banks with a lower ownership concentration, the more CEOs are rewarded with equity stakes (measured as either shares and options holdings or equity risk), the worse the bank performance both in terms of stock returns and volatility. Columns (3) and (4) follows a similar empirical strategy for the subgroup of banks with greater concentration. In this subgroup of banks we do not find any effect of shares and option holdings, while we find a positive effect of equity risk on performance during the financial crisis; equity risk has been in fact related to higher returns and lower volatility. The combination of this results go in the direction of the prediction of the model. Greater variable compensation, in the forms of equity holdings, has lead to higher risk taking (and worse performance) in banks with weaker internal supervision by shareholders. To check the robustness of this result, we substitute C3 with other proxies for the efficiency of internal supervision by exploiting some of the information contained in the World Bank III Survey on Bank Regulation and Supervision. In particular we use two proxies at country level: 1) an index of restrictions on bank activities; 2) an index of supervisory power of bank supervisory authorities. Our hypothesis is that, on one side, restrictions on bank activities by the financial authority reduces managerial slack and thus leads to higher efficiency; on the other side, higher 
power of bank supervisory authorities makes the ex-ante cost of managers' misbehavior bigger from shareholder perspective thus inducing greater internal supervision. We split the sample of banks into two sub-samples according to the values of those indices above or below the median. Results (not reported in the current version, but available upon request) show that, in the group of countries where the restrictions on bank activities were below the median, a greater variable compensation (in particular equity portfolio incentives) is related to worse performance (measured by using either stock return or standard deviation). In the other sub-group we find no effect of greater variable compensation. A similar result has been found for banks based in countries where the supervisory authority is less powerful. The combination of these empirical findings suggest that weak supervision (due to higher internal supervision costs), combined with higher pay-for-performance sensitivity in CEOs compensation schemes, might explain higher risk-taking in banks.

\subsection{Deposit insurance}

Theoretical insights from the version of our model that incorporates a risk-sensitive deposit insurance mechanism imply that, when the effect of variable compensation on risk is positive, the existence of a fair insurance premium reduces even more the risk of the bank. The opposite is true when, instead, higher variable compensation implies higher risk incentives for insiders. Again, these results call for an empirical test of the predictions of the model. In the current subsection, similarly to the previous one, we analyze the interaction between deposit insurance and variable compensation on risk in banks. To this purpose, we divide our initial sample of banks into two groups: banks based in countries where an explicit deposit insurance arrangement was in place in 2006 and banks in countries without it (which we label as countries with implicit deposit insurance system). As a first step, we check if there is a significant difference in the average compensation schemes adopted in the two groups of banks. Evidence in table 8 reveals that the group of banks with explicit deposit insurance have rewarded more equity bonus to their CEOs; however the small sample size of the other group doesn't make the statistical comparison reliable.

Insert Table 8 here 
Keeping this sample limitation in mind, we test if the interaction of explicit deposit insurance with the compensation structure has impacted on performance of banks during the financial crisis. While showing the results also for the other sub-sample for the sake of completeness, we are aware that the small sample size reduces our confidence in the statistical significance of the results. We employ a regression analysis similar in the spirit of previous section. Results are in Table 9.

\section{Insert Table 9 here}

Columns (3) and (4) replicates the regression analysis of the full specification in column (6) of tables 4 and 5 for the subsample of banks that operates in countries with explicit deposit insurance. Results in column (3) suggest that banks with equity incentives for their CEOs (both shares and options holdings and the equity risk) are associated with a worse performance in terms of stock returns during the financial crisis. Results in column (4) suggests, instead, that only equity risk has been associated to higher volatility. Taken together, theoretically insights and empirical results, suggest that explicit deposit insurance, combined with variable compensation schemes, increases the risk attitude of shareholders and managers and resulted in worse performance during the financial crisis.

\subsection{Capital requirements}

In this last subsection, we study the empirical relation between capital requirements, variable compensation and risk-taking. Theoretical insights from the model suggests that higher capital ratio (and, consequently lower leverage) might lead to lower risktaking from shareholders perspective as larger capital ratio increases the marginal revenues of their effort. As a proxy for capital requirements we employ the Tier 1 capital adequacy ratio. We, in fact, find a strong positive correlation between Tier 1 ratio and equity to total asset ratio in our sample of banks. Given that the level of Tier 1 in banks might be also the result of the moral suasion of the financial authority in a country, we prefer to use this, rather than leverage, as a measure for capital requirements at bank level. Accordingly we split our sample of banks into two groups according to the value of their Tier 1 capital ratio, below or above the median. We first examine if there is a significant difference in the average compensation schemes 
adopted in the two groups of banks. Evidence from table 10 shows that there is not a significant difference with respect to balance sheet and CEO compensation variables between the banks in the two groups; instead we find that more capitalized banks performed better during the financial crisis as opposite to the poorly capitalized banks, confirming results in section 4 .

\section{Insert Table 10 here}

As a second step, we check if there has been an interaction effect of capital requirements and the compensation structure in explaining cross-sectional heterogeneity in performance during the financial crisis. We use a regression analysis similar to that in the previous section. Results are in Table 11.

\section{Insert Table 11 here}

Results in columns (1) and (3) show that variable compensation is not associated to BHR in any of the two subgroups. Results in column (2) show, instead, that in the sub-group of poorly capitalized banks, cash bonus and equity risk has been related to higher volatility, while shares and options ownership has attenuated the negative effect of variable compensation. Results in column (4) show that there has been no effect of variable compensation on volatility for better capitalized banks. Overall we find a weak evidence that variable compensation can be related to worse performance during the financial crisis for poorly capitalized banks.

\section{Conclusions}

This paper contributes to the recent literature about the determinants of risk-taking in banks; in particular we analyze the effect of CEOs' variable compensation and its interaction with shareholders' incentives and financial regulation. We provide a theoretical framework in order to gain insights in terms of the determinants of risk taking in banks when the agency conflicts between managers, shareholders and depositors are salient drivers; moreover we test theoretical predictions by analyzing the performance of banks during the financial crisis by exploiting a novel database with banks from different countries. Coherently with main theoretical predictions, by exploiting bank level heterogeneity and cross-country differences in banking regulations, we find 
that pay-for-performance sensitivity given by CEOs equity portfolio has negatively affected the performance of banks during the financial crisis when: 1) efficiency of supervision by shareholders' on delegated managers is lower; 2) explicit deposit insurance system is in place in the country where the bank operates. We also find weaker evidence of negative relation between variable compensation and stock return volatility for poorly capitalized banks. This paper represents a first step towards the study of the joint relation between bank risk taking, CEO monetary incentives, and financial regulation both from a theoretical and an empirical point of view. The understanding of these interactions may have important policy implications in the current debate about financial regulations for banks and for managerial compensation. In particular, we show that, the direct regulation of managerial compensations alone, without controlling for the incentives of shareholders, may not effectively change risk-taking behavior of banks. 


\section{References}

Beltratti A., Stulz R.M. (2012). The credit crisis around the globe: Why did some banks perform better? Journal of Financial Economics, vol. 105, n. 1, pp. 1-17

Benmelech E., Kandel E., Veronesi P. (2010). Stock-based compensation and CEO (dis) incentives. The Quarterly Journal of Economics, vol. 125, n. 4, pp. 1769-1820

Berkovitz E., Israel R., Spiegel Y. (2000). Managerial Compensation and Capital Structure. Journal of Economics \& Management Strategy, vol. 9, n. 4, pp. 549-584.

Caprio G., Laeven L., Levine R. (2007). Governance and bank valuation. Journal of Financial Intermediation, vol. 16, n. 1, pp. $584-617$

Cerasi V., Rochet J.C. (2014), Rethinking the regulatory treatment of securitization. Journal of Financial Stability, Special issue on Finance, growth, and stability. Lessons from the crisis, vol.10, n. 1, pp.20-31

Cerasi V., Daltung S., (2007). Financial structure, managerial compensation and monitoring. Riksbank Research Paper Series No. 207

Chiang A.C. (1984),Fundamental Methods of Mathematical Economics, Mc GrawHill International, London, UK.

Core J., Guay W. (2002). Employee stock options portfolios and their sensitivities to price and volatility. Journal of Accounting Research, vol. 40, pp. 613-630

Coles, J.L., Naveen, D.D., Naveen, L. (2006). Managerial incentives and risk-taking. Journal of Financial Economics, vol. 79, n. 2, pp. 431-468

Demirguc-Kunt A., Karacaovali B., Laeven L. (2005). Deposit Insurance around the World: A Comprehensive Database. Policy Research Working Paper n. 3628, World Bank

Dewatripont M., Tirole J. (1999), The Prudential Regulation of Banks, MIT Press, Cambridge USA. 
Diamond, D.W., Rajan, R.G. (2009). The Credit Crisis: Conjectures about Causes and Remedies. The American Economic Review Papers and Proceedings, vol.99, n.2, pp. $606-610$

Ellul, A., Yerramilli, V. (2013). Stronger risk controls, lower risk: Evidence from US bank holding companies. The Journal of Finance, vol.68, n.5, pp. 1757-1803

Fahlenbrach, R., Stulz, R.M. (2011). Bank CEO incentives and the credit crisis. Journal of Financial Economics, vol. 99, n. 1, pp. 11-26

Giannetti, M., Metzger, D. (2013). Compensation and Competition for Talent: Talent Scarcity or Incentives? Available at SSRN

Gormley, T., Matsa, D., Milbourn, T. (2013). CEO compensation and corporate risk: Evidence from a natural experiment. AFA 2012 Chicago Meetings Paper

Guay, W.R. (1999). The sensitivity of CEO wealth to equity risk: an analysis of the magnitude and determinants. Journal of Financial Economics, vol.53, n.1, pp. 43-71

Jensen M., Meckling W.H. (1976). Theory of the firm: Managerial behavior, agency costs and ownership structure. Journal of Financial Economics vol. 3, Issue 4, pp. 305-360.

John K., Mehran H., Quian Y. (2010). Outside monitoring and CEO compensation in the banking industry, Journal of Corporate Finance, 16( 4), 383-399.

John K., Quian Y. (2003). Incentive features in CEO compensation in the banking industry, Federal Reserve Bank of New York Economic Policy Review.

John K. , Saunders A., Senbet L.W. (2000). A theory of bank regulation and management compensation, Review of Financial Studies, 13, 95-125.

John, T.A., John, K. (1993). Top-management compensation and capital structure. The Journal of Finance, vol.48, n.3, pp. 949-974

Laeven, L., Levine, R. (2009). Bank governance, regulation and risk taking. Journal of Financial Economics, vol. 93, n. 2, pp. 259-275 
Murphy, K.J. (1999). Executive compensation. Handbook of labor economics, vol.3, pp. $2485-2563$

Rochet J.C. (2004). Macroeconomic Shocks and Banking Supervision, Journal of Financial Stability, 1, pp. 93-110.

Shleifer, A., Vishny, R. (1986). Large shareholders and corporate control. Journal of Political Economy 94, pp. 461-488.

Suntheim F. (2010), Managerial Compensation in the Financial Service Industry. Available at SSRN 


\section{A Computations and Proofs}

\section{A.1 Proof Proposition 3}

Assume that conditions (10) and (12) are binding; after substituting the balance sheet (5) into (12), we derive equations (13) and (14). Adding the definition of probability (8), we derive the system of equations (13)-(15) which determines the equilibrium values $(\widehat{p}, \widehat{s}, \widehat{m})$.

\section{A.2 Proof Proposition 4}

To measure the sign of the impact of changes on the equilibrium values $(\widehat{p}, \widehat{s}, \widehat{m})$ we can use the Cramer Rule for systems of linear equations. To linearize the system we take the total differential of the system of equations (13)-(15) around the equilibrium values of $(\widehat{p}, \widehat{s}, \widehat{m})$ w.r.t. each of the variables of interest at the time.

\section{Effect of a change of $k$ :}

Define the matrix $D=\left[\begin{array}{ccc}0 & \frac{\widehat{\Omega}}{\widehat{s}} & \frac{\widehat{\Omega}}{(1-\widehat{m})} \\ 0 & \left(1-p_{H}\right) b & -M \\ 1 & (1-\widehat{m}) \Delta_{\phi} & \left(\Delta-\widehat{s} \Delta_{\phi}\right)\end{array}\right]$

with $\widehat{\Omega} \equiv \frac{C \widehat{s}}{(1-\widehat{m}) \Delta_{\phi}}$ and determinant:

$$
|D| \equiv-\frac{\widehat{\Omega}}{\widehat{s}(1-\widehat{m})}\left\{M(1-\widehat{m})+\left(1-p_{H}\right) b \widehat{s}\right\}<0
$$

Taking the total differential of the system of equations, we derive:

$$
D \times\left[\begin{array}{c}
\frac{d \widehat{p}}{d k} \\
\frac{d \widehat{s}}{d k} \\
\frac{d m}{d k}
\end{array}\right]=\left[\begin{array}{c}
+1 \\
0 \\
0
\end{array}\right]
$$

The sign of the effect of $k$ on the probability $\widehat{p}$ is the ratio between two determinants, i.e. $\frac{d \widehat{p}}{d k}=\frac{\left|D_{1}\right|}{|D|}$. Matrix $D_{1}$ is the $3 \times 3$ matrix given by $D$ in which the first column is substituted by the vector on the RHS of the above linear system, that is $\left|D_{1}\right|=\left(1-p_{H}\right) b\left(\Delta-\widehat{s} \Delta_{\phi}\right)+M(1-\widehat{m}) \Delta_{\phi}>0$. Given that $|D|<0$ and that $\left|D_{1}\right|>0$, the overall sign of the effect is negative, that is $\frac{d \widehat{p}}{d k}<0$. Similarly we can sign all other effects.

The sign of the effect of $k$ on the intensity $\widehat{s}$ is the ratio between two determinants, i.e. $\frac{d \widehat{s}}{d k}=\frac{\left|D_{2}\right|}{|D|}$. Matrix $D_{2}$ is the $3 \times 3$ matrix given by $D$ in which the second column is substituted by the vector on the RHS of the above linear system, that is $\left|D_{2}\right|=$ 
$-M<0$. Given that $|D|<0$ and $\left|D_{2}\right|<0$ the overall sign of the effect is positive, that is $\frac{d \widehat{s}}{d k}>0$.

Finally the sign of the effect of $k$ on the monitoring intensity $\widehat{m}$ is the ratio between two determinants, i.e. $\frac{d \widehat{m}}{d k}=\frac{\left|D_{3}\right|}{|D|}$. Matrix $D_{3}$ is the $3 \times 3$ matrix given by $D$ in which the third column is substituted by the vector on the RHS of the above linear system, that is $\left|D_{3}\right|=-\left(1-p_{H}\right) b<0$. Given that $|D|<0$ and $\left|D_{3}\right|<0$ the overall sign of the effect is positive, that is $\frac{d \widehat{m}}{d k}>0$.

Effect of a change of $C$ : taking the total differential of the system of equations w.r.t. $C$, we derive:

$$
D \times\left[\begin{array}{c}
\frac{d \widehat{p}}{d \widehat{s}} \\
\frac{d \mathscr{s}}{d \widehat{m}} \\
\frac{d \mathscr{m}}{d C}
\end{array}\right]=\left[\begin{array}{c}
-\frac{\widehat{\Omega}}{C} \\
0 \\
0
\end{array}\right]
$$

the sign of the effect of $C$ on the probability $\widehat{p}$ is the ratio between two determinants, i.e. $\frac{d \widehat{p}}{d C}=\frac{\left|E_{1}\right|}{|D|}$. Matrix $E_{1}$ is the $3 \times 3$ matrix given by $D$ in which the first column is substituted by the vector on the RHS of the above linear system, that is $\left|E_{1}\right|=$ $-\frac{\widehat{\Omega}}{C}\left\{\left(1-p_{H}\right) b\left(\Delta-\widehat{s} \Delta_{\phi}\right)+M(1-\widehat{m}) \Delta_{\phi}\right\}<0$. Given that $|D|<0$ and $\left|E_{1}\right|<0$ the overall sign of the effect is positive, that is $\frac{d \widehat{p}}{d C}>0$.

\section{A.3 Proof Proposition 5}

To measure the sign of the impact of a change in the bonus $b$ on the equilibrium values $(\widehat{p}, \widehat{s}, \widehat{m})$ we can again use the Cramer Rule for the system of linear equations (13)-(15) around the equilibrium values of $(\widehat{p}, \widehat{s}, \widehat{m})$. Taking the total differential of the system of equations w.r.t. $b$, we have:

$$
D \times\left[\begin{array}{c}
\frac{d \widehat{p}}{d b} \\
\frac{d s}{d b} \\
\frac{d m}{d b}
\end{array}\right]=\left[\begin{array}{c}
-1 \\
-\left[\Delta+\widehat{s}\left(1-p_{H}\right)\right] \\
0
\end{array}\right]
$$

where $D$ is the matrix defined in the previous Proposition. The sign of the effect of $b$ on the probability $\widehat{p}$ is the ratio between two determinants, i.e. $\frac{d \widehat{p}}{d b}=\frac{\left|F_{1}\right|}{|D|}$. Matrix $F_{1}$ is the $3 \times 3$ matrix given by $D$ in which the first column is substituted by the vector on the RHS of the above linear system, that is

$$
\left|F_{1}\right|=-\left[\left(1-p_{H}\right) b\left(\Delta-\widehat{s} \Delta_{\phi}\right)+M(1-\widehat{m}) \Delta_{\phi}\right]+\frac{\widehat{\Omega}}{\widehat{s}}\left[\Delta+\widehat{s}\left(1-p_{H}\right)\right]\left[\Delta-2 \widehat{s} \Delta_{\phi}\right]
$$


The sign of the effect is ambiguous. Given that $|D|<0$ the overall sign of the effect depends upon $\left|F_{1}\right|$. The overall effect is negative whenever $\left|F_{1}\right|$ is positive, and viceversa.

The sign of the effect of $b$ on the supervision intensity $\widehat{s}$ is the ratio between two determinants, i.e. $\frac{d \widehat{s}}{d b}=\frac{\left|F_{2}\right|}{|D|}$. Matrix $F_{2}$ is the $3 \times 3$ matrix given by $D$ in which the second column is substituted by the vector on the RHS of the above linear system, that is

$$
\left|F_{2}\right|=M+\frac{\widehat{\Omega}}{(1-\widehat{m})}\left[\Delta+\widehat{s}\left(1-p_{H}\right)\right]>0
$$

Given that $|D|<0$ and $\left|F_{2}\right|>0$ the overall sign of the effect is negative, that is $\frac{d \widehat{s}}{d b}<0$.

Finally the sign of the effect of $b$ on the monitoring intensity $\widehat{m}$ is the ratio between two determinants, i.e. $\frac{d \widehat{m}}{d b}=\frac{\left|F_{3}\right|}{|D|}$. Matrix $F_{3}$ is the $3 \times 3$ matrix given by $D$ in which the third column is substituted by the vector on the RHS of the above linear system, that is

$$
\left|F_{3}\right|=-\frac{\widehat{\Omega}}{\widehat{s}}\left[\Delta+\widehat{s}\left(1-p_{H}\right)\right]+\left(1-p_{H}\right) b
$$

when the last term is not too large (small $b$ ) then $\left|F_{3}\right|<0$, and given that $|D|<0$ the overall sign of the effect is positive, that is $\frac{d \widehat{m}}{d b}>0$. However for a larger $b$ the sign might be reversed.

\section{A.4 Proposition 7 and its proof.}

Proposition 7 A larger bonus b has a negative effect on the intensity of supervision $\widetilde{s}$ of the banker, while it might improve the monitoring effort $\widetilde{m}$ of the manager. Overall a larger bonus has an ambiguous effect on the probability of loan losses $\widetilde{p}$.

Proof. The sign of the impact of a change in the bonus $b$ on the equilibrium values $(\widetilde{p}, \widetilde{s}, \widetilde{m})$ can be derived by applying the Cramer Rule for the system of linear equations (18)-(20) at the equilibrium values of $(\widetilde{p}, \widetilde{s}, \widetilde{m})$. Taking the total differential of the system of equations w.r.t. $b$, we have:

$$
G \times\left[\begin{array}{c}
\frac{d \widetilde{p}}{d b} \\
\frac{d s}{d b} \\
\frac{d m}{d b}
\end{array}\right]=\left[\begin{array}{c}
-(1-\widetilde{p}) \\
-\left[\Delta+\widetilde{s}\left(1-p_{H}\right)\right] \\
0
\end{array}\right]
$$


where $G$ is the following matrix:

$$
G=\left[\begin{array}{ccc}
-[(b-\ell)+\widetilde{\Omega}] & \widetilde{\Omega} \frac{(1-\widetilde{p})}{\widetilde{s}} & \widetilde{\Omega} \frac{(1-\widetilde{p})}{(1-\widetilde{m})} \\
0 & \left(1-p_{H}\right) b & -M \\
1 & (1-\widetilde{m}) \Delta_{\phi} & \left(\Delta-\widetilde{s} \Delta_{\phi}\right)
\end{array}\right]
$$

The sign of the effect of $b$ on the probability $\widetilde{p}$ is the ratio between two determinants, i.e. $\frac{d \widetilde{p}}{d b}=\frac{\left|G_{1}\right|}{|G|}$. Matrix $G_{1}$ is the $3 \times 3$ matrix given by $G$ in which the first column is substituted by the vector on the RHS of the above linear system, that is $\left|G_{1}\right|=(1-\widetilde{p})\left\{-\left[\left(1-p_{H}\right) b\left(\Delta-\widetilde{s} \Delta_{\phi}\right)+M(1-\widetilde{m}) \Delta_{\phi}\right]+\frac{\widetilde{\Omega}}{\widetilde{s}}\left[\Delta+\widetilde{s}\left(1-p_{H}\right)\right]\left[\Delta-2 \widetilde{s} \Delta_{\phi}\right]\right\}$.

The sign of the effect is ambiguous. Given that $|G|=-[(b-\ell)+\widetilde{\Omega}]\left[\left(1-p_{H}\right) b\left(\Delta-\widetilde{s} \Delta_{\phi}\right)+M(1-\widetilde{m}) \Delta_{\phi}\right]-(1-\widetilde{p}) \frac{\widetilde{\Omega}}{\widetilde{s}(1-\widetilde{m})}\left[M(1-\widetilde{m})+\left(1-p_{H}\right)\right.$ the overall sign of the effect depends upon $\left|G_{1}\right|$. The overall effect is negative whenever $\left|G_{1}\right|$ is positive, and viceversa. The sign of the effect of $b$ on the supervision intensity $\widetilde{s}$ is the ratio between two determinants, i.e. $\frac{d \widetilde{s}}{d b}=\frac{\left|G_{2}\right|}{|G|}$. Matrix $G_{2}$ is the $3 \times 3$ matrix given by $G$ in which the second column is substituted by the vector on the RHS of the above linear system, that is

$\left|G_{2}\right|=[(b-\ell)+\widetilde{\Omega}]\left[\Delta+\widetilde{s}\left(1-p_{H}\right)\right]\left(\Delta-\widetilde{s} \Delta_{\phi}\right)+(1-\widetilde{p})\left\{M+\frac{\widetilde{\Omega}}{(1-\widetilde{m})}\left[\Delta+\widetilde{s}\left(1-p_{H}\right)\right]\right\}>0$

Given that $|G|<0$ and $\left|G_{2}\right|>0$ the overall sign of the effect is negative, that is $\frac{d \widetilde{s}}{d b}<0$.Finally the sign of the effect of $b$ on the monitoring intensity $\widetilde{m}$ is the ratio between two determinants, i.e. $\frac{d \widetilde{m}}{d b}=\frac{\left|G_{3}\right|}{|G|}$. Matrix $G_{3}$ is the $3 \times 3$ matrix given by $G$ in which the third column is substituted by the vector on the RHS of the above linear system, that is

$$
\left|G_{3}\right|=-\left[\Delta+\widetilde{s}\left(1-p_{H}\right)\right]\left\{[(b-\ell)+\widetilde{\Omega}](1-\widetilde{m}) \Delta_{\phi}+(1-\widetilde{p}) \frac{\widetilde{\Omega}}{\widetilde{s}}\right\}+(1-\widetilde{p})\left(1-p_{H}\right) b
$$

when the last term is not too large (small $b$ ) then $\left|G_{3}\right|<0$, and given that $|G|<0$ the overall sign of the effect is positive, that is $\frac{d \tilde{m}}{d b}>0$. 


\section{B Definition of key variables and Data source}

\section{Balance sheet - Bankscope}

- Total Assets: Total earning assets plus Cash and due from banks plus Foreclosed real estate plus Fixed assets plus Goodwill plus Other intangibles plus Current tax assets plus deferred tax plus Discontinued operations plus Other assets in 2006

- Total Liabilities: Total interest-bearing liabilities plus Fair value portion of debt plus Credit impairment reserves plus Reserves for pension and other plus Tax liabilities plus Other deferred liabilities plus Discontinued operations plus Insurance plus Other non-interest-bearing liabilities in 2006

- Market capitalization: total number of shares at the end of 2006 multiplied by the price of shares at the end of 2006.

- Total Equity: Common equity plus Non-controlling interest plus Securities revaluation reserves plus Foreign Exchange Revaluation Reserves plus other revaluation reserves in 2006

- Equity ratio (book value): total equity (book value from Bankscope) over total assets in 2006

- Net income: pre-tax profit in 2006

- Book to Market ratio: Market value of equity (total number of shares multiplied by end of year price of share at the end of 2006 - source Datastream) over Total equity (book value from Bankscope)

- Tier1 Capital ratio: This is regulatory measure of capital adequacy. That is shareholder funds plus perpetual non cumulative preference shares as a percentage of risk weighted assets and off balance sheet risks measured under the Basel rules.

- Tangible asset ratio: This is like a pure leverage ratio but it removes goodwill or any other intangible asset from both equity and the asset side of the balance sheet as in difficulty a banks's intangible may be worthless. 
- Market return from stock prices 2005 - 2006: share price at the end of 2006 plus dividend per share in 2006 minus the price at the end of 2005 all over the price of shares at the end of 2005 .

\section{Compensation - Capital IQ People Intelligence}

- Total compensation: Salary plus Cash bonus plus Equity bonus paid in 2006

- Salary: amount paid as fixed salary in 2006

- Cash bonus: amount paid in cash as bonus in 2006

- Equity bonus: it is the value of bonus not paid in cash in 2006; it sums up restricted stock awards, stock grant awards and option awards (the value of options)

- Cash bonus over salary: Cash bonus over Salary

- Total bonus over salary: total bonus (Cash bonus plus Equity bonus) over Salary

- Cash bonus over total bonus: Cash bonus over Total bonus

- Value of shares: Number of shares (unrestricted and restricted) held by the CEO multiplied by the price of share at the end of 2006

- Value of stock options: it is the value of options calculated using the Black and Scholes formula; the exercise price and the share price at the end of the year and the expiration year is provided by Capital IQ. The risk-free interest rate is the 10-year maturity interest rate on US bonds (source: Federal Reserve). The total number of options is given by the sum of exercisable options, unexercisable options, unearned and unexercised options. Unexercised options have been excluded from the sum of total options

- Value of total equity portfolio: Value of shares plus Value of stock options

- Value of total equity portfolio/Total compensation: Value of total equity portfolio over Total compensation 
- Ownership from shares (\%): it is the ratio between Number of shares held by the CEO (source: Capital IQ) and Total number of shares of the company (source: Datastream) multiplied by 100

- Delta-weighted options: sum of each option held by the CEO at the end of 2006 multiplied by the delta of the respective option (sensitivity of CEO option portfolio value to share price calculated using the formula by Core and Guay (2002))

- Ownership from shares and options (\%): Ownership from shares (\%) plus the Delta-weighted options divided (see below) divided by the total number of shares outstanding

- Percentage equity risk (\%) (vega of options) sensitivity of CEO option portfolio value to stock return volatility. It is the weighted sum of the vegas of each option held by the CEO at the end of 2006; the weights are determined by the number of each option award divided by total number of options. It is multiplied by 100.

\section{Stock returns - Datastream}

- Buy and hold return 2007-2008: buy and hold return (weekly returns) on banks' stock over the period 2007:III-2008:IV

- Risk return 2007-2008: standard deviation of weekly returns over the period 2007:III-2008:IV

\section{Regulation - III Survey on Bank Regulation and Supervision}

- Official: an index of the power of the commercial bank supervisory agency, including elements such as the rights of the supervisor to meet with and demand information from auditors, to force a bank to change the internal organizational structure, to supersede the rights of shareholders, and to intervene in a bank

- Deposit insurance: dummy variable equal to 1 if the country has an explicit deposit insurance 
- Restrict: an index of regulatory restrictions on the activities of banks, consisting, for example, of limitations in the ability of banks to engage in securities market activities, insurance activities, real estate activities, and to own nonfinancial firms 


\section{Tables}

Table 1: List of banks

\begin{tabular}{|c|c|}
\hline Country & Name of the bank \\
\hline \multirow[t]{6}{*}{ AUSTRALIA } & Australia and New Zealand Banking Group Limited \\
\hline & National Australia Bank Limited \\
\hline & Bendigo and Adelaide Bank Limited \\
\hline & Bank of Queensland Ltd. \\
\hline & Westpac Banking Corporation \\
\hline & Commonwealth Bank of Australia \\
\hline AUSTRIA & Erste Group Bank AG \\
\hline BELGIUM & Dexia SA \\
\hline \multirow[t]{9}{*}{ CANADA } & The Toronto-Dominion Bank \\
\hline & Laurentian Bank of Canada \\
\hline & Royal Bank of Canada \\
\hline & The Bank of Nova Scotia \\
\hline & Home Capital Group Inc. \\
\hline & Canadian Imperial Bank of Commerce \\
\hline & National Bank of Canada \\
\hline & Bank of Montreal \\
\hline & Canadian Western Bank \\
\hline CHINA & China Merchants Bank Co. Ltd. \\
\hline CZECH REPUBLIC & Komercni Banka AS \\
\hline DENMARK & Danske Bank A/S \\
\hline \multirow{3}{*}{ FRANCE } & Credit Agricole S.A. \\
\hline & BNP Paribas SA \\
\hline & Societe Generale Group \\
\hline \multirow{4}{*}{ GERMANY } & Commerzbank AG \\
\hline & Aareal Bank AG \\
\hline & Deutsche Postbank AG \\
\hline & Deutsche Bank AG \\
\hline \multirow[t]{7}{*}{ HONG KONG } & Dah Sing Financial Holdings Limited \\
\hline & Hang Seng Bank Limited \\
\hline & The Bank of East Asia, Limited \\
\hline & Wing Hang Bank Limited \\
\hline & BOC Hong Kong Holdings Ltd. \\
\hline & Chong Hing Bank Limited \\
\hline & Dah Sing Banking Group Limited \\
\hline \multirow[t]{5}{*}{ INDIA } & Bank of Baroda \\
\hline & ICICI Bank Ltd. \\
\hline & Housing Development Finance Corporation Limited \\
\hline & Oriental Bank of Commerce \\
\hline & HDFC Bank Ltd. \\
\hline \multirow[t]{2}{*}{ IRELAND } & Allied Irish Banks p.l.c. \\
\hline & The Governor and Company of the Bank of Ireland \\
\hline \multirow[t]{6}{*}{ ISRAEL } & Israel Discount Bank Limited \\
\hline & Bank Leumi Le-Israel BM \\
\hline & First International Bank of Israel Ltd. \\
\hline & Mizrahi Tefahot Bank, Ltd. \\
\hline & Union Bank of Israel Ltd. \\
\hline & Bank Hapoalim B.M. \\
\hline
\end{tabular}


Continuation of Table 1

\begin{tabular}{|c|c|}
\hline Country & Name of the bank \\
\hline \multirow[t]{6}{*}{ ITALY } & Unione di Banche Italiane Scpa \\
\hline & Banca Popolare di Sondrio \\
\hline & UniCredit S.p.A. \\
\hline & Banco Popolare Societa Cooperativa Scarl \\
\hline & Banca Carige S.p.A. \\
\hline & Banca popolare dell'Emilia Romagna \\
\hline \multirow[t]{4}{*}{ JORDAN } & Arab Bank plc \\
\hline & Capital Bank of Jordan \\
\hline & Bank of Jordan \\
\hline & Cairo Amman Bank \\
\hline MALASYA & Malayan Banking Berhad \\
\hline NAMIBIA & FNB Namibia Holdings Limited \\
\hline NETHERLANDS & Van Lanschot NV \\
\hline \multirow[t]{9}{*}{ NORWAY } & Dnb Asa \\
\hline & Helgeland Sparebank \\
\hline & Sandnes Sparebank \\
\hline & SpareBank 1 Nord-Norge \\
\hline & SpareBank 1 SMN \\
\hline & SpareBank 1 SR-Bank \\
\hline & SpareBank1 Buskerud-Vestfold \\
\hline & Sparebanken M.re \\
\hline & Sparebanken Pluss \\
\hline \multirow[t]{9}{*}{ PAKISTAN } & NIB Bank Limited \\
\hline & Faysal Bank Limited \\
\hline & Habib Metropolitan Bank Limited \\
\hline & United Bank Ltd. \\
\hline & Bank Al Habib Limited \\
\hline & Bank Alfalah Limited \\
\hline & Allied Bank Limited \\
\hline & MCB Bank Ltd. \\
\hline & Askari Bank Limited \\
\hline \multirow[t]{5}{*}{ POLAND } & Bank Polska Kasa Opieki \\
\hline & Bank Millennium Spolka Akcyjna \\
\hline & BRE Bank SA \\
\hline & Bank Zachodni WBK SA \\
\hline & Bank Handlowy W Warszawie SA \\
\hline \multirow[t]{7}{*}{ SOUTH AFRICA } & Absa Group Limited \\
\hline & Standard Bank Group Limited \\
\hline & Capitec Bank Holdings Ltd. \\
\hline & FirstRand Limited \\
\hline & Sasfin Holdings Limited \\
\hline & Cadiz Holdings Ltd. \\
\hline & Nedbank Group Limited \\
\hline \multirow[t]{3}{*}{ SPAIN } & Banco Popular Espanol S.A. \\
\hline & Banco Santander, S.A. \\
\hline & Banco Bilbao Vizcaya Argentaria, S.A. \\
\hline \multirow[t]{4}{*}{ SWEDEN } & Nordea Bank AB \\
\hline & Swedbank AB \\
\hline & Skandinaviska Enskilda Banken AB \\
\hline & Svenska Handelsbanken AB \\
\hline
\end{tabular}


Continuation of Table 1

\begin{tabular}{cc}
\hline Country & Name of the bank \\
\hline UNITED KINGDOM & HSBC Holdings plc \\
Standard Chartered plc \\
Paragon Group of Companies plc \\
The Royal Bank of Scotland Group plc \\
Arbuthnot Banking Group plc \\
Barclays plc \\
Lloyds Banking Group plc \\
U.S. Bancorp \\
Fifth Third Bancorp \\
SunTrust Banks, Inc. \\
Regions Financial Corporation \\
BBandT Corporation \\
Citigroup, Inc. \\
JPMorgan Chase and Co. \\
Bank of America Corporation \\
The PNC Financial Services Group, Inc. \\
Wells Fargo and Company \\
SLM Corporation \\
The Bank of New York Mellon Corporation \\
\hline
\end{tabular}

Table 2: Summary Statistics for the sample of banks

\begin{tabular}{|c|c|c|c|c|}
\hline & Mean & St. Dev. & Median & Number \\
\hline \multicolumn{5}{|l|}{ Panel A:Descriptive statistics in 2006} \\
\hline Total Assets & 287171.4 & 558105.1 & 61590.9 & 116 \\
\hline Total Liabilities & 270839.8 & 528171.2 & 56701.26 & 116 \\
\hline Market capitalization & 49713.84 & 236197.1 & 7491.345 & 116 \\
\hline Net income over total asset & .0133893 & .0123198 & .0104837 & 116 \\
\hline Equity (book value) over total asset & .0768866 & .0513843 & .0654814 & 116 \\
\hline Equity book to market ratio & .9652698 & 1.339303 & .6215296 & 116 \\
\hline Tier1 Capital Ratio & 9.5378 & 3.009371 & 8.61 & 100 \\
\hline Tangible asset ratio & 6.422155 & 4.722926 & 5.4 & 116 \\
\hline Market return from stock prices 2005-2006 & .2759742 & .26403 & .2703018 & 116 \\
\hline \multicolumn{5}{|l|}{ Panel B: Perfomance variables in the financial crisis } \\
\hline Buy and hold return 2007-2008 & -.4833044 & .2581407 & -.4886037 & 116 \\
\hline Standard deviation 2007-2008 & .0664146 & .0198295 & .0640443 & 116 \\
\hline
\end{tabular}


Table 3: Summary Statistics for CEO compensations

\begin{tabular}{lcccc}
\hline \hline & Mean & St. Dev. & Median & Number \\
\hline Panel A:Annual Compensation 2006 & & & & \\
Total compensation & 3576.3 & 6029.7 & 1353.7 & 116 \\
Salary & 798.5 & 573.1 & 758.1 & 116 \\
Cash bonus & 1410.1 & 2468.2 & 429.3 & 116 \\
Equity bonus & 1367.7 & 3889.8 & 0 & 116 \\
Cash bonus over salary & 1.5 & 2.4 & 0.6 & 116 \\
Equity bonus over salary & 1.387673 & 3.892764 & 0 & 116 \\
Total bonus over salary & 2.886128 & 5.755734 & .9707452 & 116 \\
Cash bonus over total bonus & 0.5 & 0.4 & 0.6 & 116 \\
\hline Panel B:Equity portfolio value & & & & \\
Value of shares & 16385.6 & 41417.1 & 725.4 & 116 \\
Value of options & 19002.6 & 67158.2 & 0 & 116 \\
Value of total equity portfolio & 35388.2 & 90413.2 & 1068.7 & 116 \\
Value of total equity portfolio/Total compensation & 21.4 & 93.9 & 1.1 & 116 \\
Value of total equity portfolio/Salary & 48.4612 & 125.4424 & 1.937246 & 116 \\
\hline Panel C: Equity portfolio incentives & & & & \\
Ownership from shares (\%) & 1.4 & 6.5 & .02 & 116 \\
Ownership from shares and options (\%) & 1.5 & 6.5 & .02 & 116 \\
Percentage equity risk (vega of options) (\%) & 0.7 & 2.4 & 0 & 116 \\
\hline \hline
\end{tabular}

The table provides summary statistics for the sample of the compensation and the portfolio of equity of CEOs appointed in the selected banks in 2006. The definition of the variables are in the Appendix. All variables in Panel A and Panel B are measured in US dollars at the end of Fiscal Year 2006.

Table 4: Estimation results: Buy and hold returns 2007:III-2008:IV (BHR_0708)

\begin{tabular}{|c|c|c|c|c|c|c|}
\hline \multirow[t]{2}{*}{ Dependent variable: } & \multicolumn{6}{|c|}{ "BHR_0708 } \\
\hline & (1) & (2) & (3) & (4) & (5) & $(6)$ \\
\hline Cash bonus over salary & $\begin{array}{c}-0.0107 \\
(0.0104)\end{array}$ & & & $\begin{array}{c}-0.00294 \\
(0.0119)\end{array}$ & $\begin{array}{c}-0.00867 \\
(0.0122)\end{array}$ & $\begin{array}{l}0.00300 \\
(0.0119)\end{array}$ \\
\hline Ownership from shares and options & & $\begin{array}{c}0.386 \\
(0.384)\end{array}$ & & $\begin{array}{l}-0.165 \\
(0.284)\end{array}$ & $\begin{array}{l}-0.192 \\
(0.294)\end{array}$ & $\begin{array}{l}-0.476 \\
(0.317)\end{array}$ \\
\hline Equity risk (option vega) & & & $\begin{array}{l}-1.499 \\
(0.936)\end{array}$ & $\begin{array}{l}-1.689^{*} \\
(0.953)\end{array}$ & $\begin{array}{l}-1.812^{*} \\
(0.935)\end{array}$ & $\begin{array}{l}-1.228 \\
(0.968)\end{array}$ \\
\hline Stock market return & & & & $\begin{array}{c}-0.342^{* * *} \\
(0.0946)\end{array}$ & $\begin{array}{c}-0.329^{* * *} \\
(0.0891)\end{array}$ & $\begin{array}{c}-0.316^{* * *} \\
(0.0867)\end{array}$ \\
\hline Book to market & & & & $\begin{array}{c}-0.0464^{* *} \\
(0.0201)\end{array}$ & $\begin{array}{l}-0.0364^{*} \\
(0.0189)\end{array}$ & $\begin{array}{c}-0.0478^{* * *} \\
(0.0177)\end{array}$ \\
\hline Log(market capitalization) & & & & $\begin{array}{l}-0.0176 \\
(0.0145)\end{array}$ & $\begin{array}{r}-0.00633 \\
(0.0151)\end{array}$ & $\begin{array}{l}-0.0188 \\
(0.0140)\end{array}$ \\
\hline Equity ratio (book value) & & & & & $\begin{array}{c}0.855 \\
(0.565)\end{array}$ & $\begin{array}{c}0.987 \\
(1.105)\end{array}$ \\
\hline Tier 1 Capital Ratio & & & & & & $\begin{array}{c}0.0180^{*} \\
(0.0104)\end{array}$ \\
\hline Constant & $\begin{array}{r}-0.467^{* * *} \\
(0.0295)\end{array}$ & $\begin{array}{r}-0.489^{* * *} \\
(0.0246)\end{array}$ & $\begin{array}{c}-0.473^{* * *} \\
(0.0245)\end{array}$ & $\begin{array}{l}-0.177 \\
(0.149)\end{array}$ & $\begin{array}{c}-0.342^{* *} \\
(0.167)\end{array}$ & $\begin{array}{c}-0.414^{* *} \\
(0.161)\end{array}$ \\
\hline$N$ & 116 & 116 & 116 & 116 & 116 & 100 \\
\hline adj. $R^{2}$ & 0.001 & 0.001 & 0.010 & 0.124 & 0.139 & 0.240 \\
\hline
\end{tabular}

Robust standard errors in parentheses. ${ }^{*} p<0.10,{ }^{* *} p<0.05,{ }^{* * *} p<0.01$. All covariates are measured in US dollars at the end of Fiscal Year 2006. 
Table 5: Estimation results: Standard deviation 2007:III-2008:IV (SD 0708)

\begin{tabular}{|c|c|c|c|c|c|c|}
\hline \multirow[t]{2}{*}{ Dependent variable: } & \multicolumn{6}{|c|}{ SD_0708 } \\
\hline & (1) & $(2)$ & (3) & (4) & (5) & (6) \\
\hline Cash bonus over salary & $\begin{array}{c}0.00104 \\
(0.000696)\end{array}$ & & & $\begin{array}{c}0.000325 \\
(0.000791)\end{array}$ & $\begin{array}{c}0.000848 \\
(0.000826)\end{array}$ & $\begin{array}{c}0.000369 \\
(0.000789)\end{array}$ \\
\hline Ownership from shares and options & & $\begin{array}{c}-0.0535^{* * *} \\
(0.0102)\end{array}$ & & $\begin{array}{c}-0.0399^{* * *} \\
(0.0133)\end{array}$ & $\begin{array}{c}-0.0375^{* * *} \\
(0.0134)\end{array}$ & $\begin{array}{l}-0.0183 \\
(0.0132)\end{array}$ \\
\hline Equity risk (option vega) & & & $\begin{array}{c}0.191^{* *} \\
(0.0959)\end{array}$ & $\begin{array}{c}0.179^{*} \\
(0.0970)\end{array}$ & $\begin{array}{c}0.190^{* *} \\
(0.0922)\end{array}$ & $\begin{array}{c}0.129 \\
(0.0791)\end{array}$ \\
\hline Stock market return & & & & $\begin{array}{c}0.0154^{* *} \\
(0.00614)\end{array}$ & $\begin{array}{c}0.0141^{* *} \\
(0.00589)\end{array}$ & $\begin{array}{l}0.0192^{* * *} \\
(0.00439)\end{array}$ \\
\hline Book to market & & & & $\begin{array}{c}-0.00338^{* * *} \\
(0.00101)\end{array}$ & $\begin{array}{c}-0.00428^{* * *} \\
(0.00133)\end{array}$ & $\begin{array}{c}-0.00221^{* *} \\
(0.000918)\end{array}$ \\
\hline $\log ($ market capitalization $)$ & & & & $\begin{array}{c}-0.000170 \\
(0.00104)\end{array}$ & $\begin{array}{c}-0.00120 \\
(0.00126)\end{array}$ & $\begin{array}{c}0.000540 \\
(0.000931)\end{array}$ \\
\hline Equity ratio (book value) & & & & & $\begin{array}{c}-0.0779^{* *} \\
(0.0345)\end{array}$ & $\begin{array}{l}-0.0628 \\
(0.0815)\end{array}$ \\
\hline Tier 1 Capital Ratio & & & & & & $\begin{array}{c}-0.000171 \\
(0.000767)\end{array}$ \\
\hline Constant & $\begin{array}{c}0.0649^{* * *} \\
(0.00209)\end{array}$ & $\begin{array}{l}0.0672^{* * *} \\
(0.00189)\end{array}$ & $\begin{array}{l}0.0651^{* * *} \\
(0.00181)\end{array}$ & $\begin{array}{l}0.0658^{* * *} \\
(0.00995)\end{array}$ & $\begin{array}{c}0.0808^{* * *} \\
(0.0141)\end{array}$ & $\begin{array}{l}0.0615^{* * *} \\
(0.00960)\end{array}$ \\
\hline $\begin{array}{l}N \\
\text { adj. } R^{2}\end{array}$ & $\begin{array}{c}116 \\
0.007\end{array}$ & $\begin{array}{c}116 \\
0.023\end{array}$ & $\begin{array}{c}116 \\
0.044\end{array}$ & $\begin{array}{c}116 \\
0.144\end{array}$ & $\begin{array}{c}116 \\
0.169\end{array}$ & $\begin{array}{c}100 \\
0.218\end{array}$ \\
\hline
\end{tabular}

$\overline{\text { Robust standard errors in parentheses. }{ }^{*} p<0.10,{ }^{* *} p<0.05,{ }^{* * *} p<0.01 \text {. All covariates are measured in US dollars at the end of }}$ Fiscal Year 2006.

Table 6: Compensation structure and ownership concentration

\begin{tabular}{|c|c|c|c|}
\hline & C3 below median & C3 above median & Difference \\
\hline \multicolumn{4}{|l|}{ Panel A:Bank level descriptive statistics } \\
\hline Total Assets & $\begin{array}{c}413958.2 \\
(690077.5)\end{array}$ & $\begin{array}{c}160384.6 \\
(345696.9)\end{array}$ & $253573.6^{*}$ \\
\hline Market capitalization & $\begin{array}{c}86977.7 \\
(330701.1)\end{array}$ & $\begin{array}{c}12449.9 \\
(19175.7)\end{array}$ & 74527.8 \\
\hline Equity (book value) over total assets & $\begin{array}{c}0.0714 \\
(0.0340)\end{array}$ & $\begin{array}{c}0.0824 \\
(0.0641)\end{array}$ & -0.0109 \\
\hline Market return from stock prices 2005-2006 & $\begin{array}{c}0.267 \\
(0.254)\end{array}$ & $\begin{array}{c}0.285 \\
(0.276)\end{array}$ & -0.0109 \\
\hline Tier1 Capital Ratio & $\begin{array}{c}9.276 \\
(3.096)\end{array}$ & $\begin{array}{c}9.810 \\
(2.923)\end{array}$ & -0.534 \\
\hline \multicolumn{4}{|l|}{ Panel B: Compensation variables } \\
\hline Cash bonus over salary & $\begin{array}{c}2.144 \\
(3.079)\end{array}$ & $\begin{array}{c}0.853 \\
(1.123)\end{array}$ & $1.291^{* *}$ \\
\hline Equity bonus over salary & $\begin{array}{c}2.223 \\
(5.231)\end{array}$ & $\begin{array}{c}0.553 \\
(1.338)\end{array}$ & $1.670^{*}$ \\
\hline Total bonus over salary & $\begin{array}{c}4.367 \\
(7.663)\end{array}$ & $\begin{array}{c}1.406 \\
(1.913)\end{array}$ & $2.961^{* *}$ \\
\hline Value of total equity portfolio/Total compensation & $\begin{array}{c}27.86 \\
(119.4)\end{array}$ & $\begin{array}{c}14.90 \\
(58.98)\end{array}$ & 12.96 \\
\hline \multicolumn{4}{|l|}{ Panel C: Performance variables in the financial crisis } \\
\hline Buy and hold return 2007-2008 & $\begin{array}{l}-0.499 \\
(0.272)\end{array}$ & $\begin{array}{l}-0.468 \\
(0.245)\end{array}$ & -0.0312 \\
\hline Standard deviation 2007-2008 & $\begin{array}{c}0.0691 \\
(0.0229)\end{array}$ & $\begin{array}{c}0.0638 \\
(0.0159)\end{array}$ & 0.00531 \\
\hline$N$ & 58 & 58 & \\
\hline
\end{tabular}


Table 7: Ownership concentration, variable compensation and performance in the financial crisis

\begin{tabular}{lcccc}
\hline \hline & \multicolumn{2}{c}{ Low Concentration } & \multicolumn{2}{c}{ High Concentration } \\
\hline Dependent variable & BHR & RR & BHR & RR \\
& $(1)$ & $(2)$ & $(3)$ & $(4)$ \\
\hline Cash bonus over salary & 0.00697 & 0.000373 & 0.0177 & -0.000448 \\
& $(0.0135)$ & $(0.000939)$ & $(0.0230)$ & $(0.00193)$ \\
Ownership from shares and options & $-7.361^{* * *}$ & $0.298^{* *}$ & -0.177 & -0.0175 \\
& $(2.509)$ & $(0.135)$ & $(0.320)$ & $(0.0183)$ \\
Equity risk (option vega) & $-1.902^{* *}$ & $0.171^{* *}$ & $2.114^{* * *}$ & $-0.105^{* * *}$ \\
& $(0.799)$ & $(0.0716)$ & $(0.575)$ & $(0.0386)$ \\
Stock market return & $-0.366^{* *}$ & $0.0234^{* * *}$ & $-0.347^{* * *}$ & $0.0192^{* * *}$ \\
& $(0.181)$ & $(0.00646)$ & $(0.126)$ & $(0.00680)$ \\
Book to market & $-0.126^{* * *}$ & -0.00129 & $-0.0224^{*}$ & $-0.00166^{*}$ \\
& $(0.0337)$ & $(0.00212)$ & $(0.0121)$ & $(0.000921)$ \\
Log(market capitalization) & $-0.0562^{* *}$ & 0.00154 & -0.00154 & 0.000452 \\
& $(0.0241)$ & $(0.00167)$ & $(0.0151)$ & $(0.00121)$ \\
Equity ratio (book value) & 1.444 & -0.152 & 1.245 & 0.0244 \\
Tier 1 Capital Ratio & $(1.412)$ & $(0.124)$ & $(1.672)$ & $(0.113)$ \\
& & & & \\
Constant & $0.0365^{* *}$ & -0.000123 & 0.0116 & -0.00127 \\
& $(0.0167)$ & $(0.00122)$ & $(0.0163)$ & $(0.00109)$ \\
adj. $R^{2}$ & -0.132 & $0.0544^{* * *}$ & $-0.566^{* * *}$ & $0.0669^{* * *}$ \\
\hline \hline
\end{tabular}

Robust standard errors in parentheses. ${ }^{*} p<0.10,{ }^{* *} p<0.05,{ }^{* * *} p<0.01$. All covariates are measured in US dollars at the end of Fiscal Year 2006. 
Table 8: Compensation structure and deposit insurance

\begin{tabular}{|c|c|c|c|}
\hline Panel A:Bank level descriptive statistics & Implicit Dep. Ins. & Explicit Dep. Ins. & Difference \\
\hline Total Assets & $\begin{array}{c}78758.6 \\
(95508.8)\end{array}$ & $\begin{array}{c}449614.9 \\
(675523.4)\end{array}$ & $-370856.3^{* *}$ \\
\hline Market capitalization & $\begin{array}{c}78643.9 \\
(14500.5)\end{array}$ & $\begin{array}{c}-67599.7 \\
(303572.6)\end{array}$ & 11044.2 \\
\hline Equity (book value) over total asset & $\begin{array}{c}0.0921 \\
(0.0856)\end{array}$ & $\begin{array}{c}0.0632 \\
(0.0277)\end{array}$ & $0.0289^{*}$ \\
\hline Market return from stock prices & $\begin{array}{c}0.259 \\
(0.197)\end{array}$ & $\begin{array}{c}0.272 \\
(0.174)\end{array}$ & -0.0129 \\
\hline Tier1 Capital Ratio & $\begin{array}{c}9.140 \\
(2.130)\end{array}$ & $\begin{array}{c}8.875 \\
(1.998)\end{array}$ & 0.265 \\
\hline Panel B: Compensation variables & & & \\
\hline Cash bonus over salary & $\begin{array}{c}1.269 \\
(1.215)\end{array}$ & $\begin{array}{c}1.935 \\
(2.907)\end{array}$ & -0.666 \\
\hline Equity bonus over salary & $\begin{array}{c}0.437 \\
(0.651)\end{array}$ & $\begin{array}{c}2.160 \\
(4.893)\end{array}$ & -1.723 \\
\hline Total bonus over salary & $\begin{array}{c}1.706 \\
(1.480)\end{array}$ & $\begin{array}{c}4.096 \\
(7.150)\end{array}$ & -2.389 \\
\hline Value of total equity portfolio/Total compensation & $\begin{array}{c}6.350 \\
(12.35)\end{array}$ & $\begin{array}{c}9.865 \\
(24.79) \\
\end{array}$ & -3.514 \\
\hline Panel C: Perfomance variables in the financial crisis & & & \\
\hline Buy and hold return 2007-2008 & $\begin{array}{l}-0.418 \\
(0.181)\end{array}$ & $\begin{array}{l}-0.543 \\
(0.241)\end{array}$ & $0.125^{*}$ \\
\hline Standard deviation 2007-2008 & $\begin{array}{c}0.0635 \\
(0.0125)\end{array}$ & $\begin{array}{c}0.0684 \\
(0.0228)\end{array}$ & -0.00484 \\
\hline$N$ & 27 & 69 & \\
\hline
\end{tabular}


Table 9: Deposit insurance, variable compensation and performance in the financial crisis

\begin{tabular}{lcccc}
\hline \hline & \multicolumn{2}{c}{ Implicit } & Deposit & \multicolumn{2}{c}{ Explicit } & Deposit \\
\hline Dependent variable & BHR & RR & BHR & RR \\
& $(1)$ & $(2)$ & $(3)$ & $(4)$ \\
\hline Cash bonus over salary & -0.000921 & 0.00169 & 0.00680 & 0.000600 \\
& $(0.0313)$ & $(0.00179)$ & $(0.0120)$ & $(0.000950)$ \\
Ownership from shares and options & -9.667 & -0.0708 & $-1.774^{* * *}$ & 0.0374 \\
& $(7.781)$ & $(0.665)$ & $(0.393)$ & $(0.0353)$ \\
Equity risk (option vega) & 0.404 & -0.0561 & $-1.725^{* * *}$ & $0.192^{* * *}$ \\
& $(1.098)$ & $(0.0612)$ & $(0.647)$ & $(0.0693)$ \\
Stock market return & 0.132 & $0.0367^{* *}$ & -0.0780 & 0.0222 \\
& $(0.294)$ & $(0.0130)$ & $(0.211)$ & $(0.0177)$ \\
Book to market & -0.298 & -0.0237 & $-0.0623^{* * *}$ & -0.000912 \\
& $(0.205)$ & $(0.0141)$ & $(0.0227)$ & $(0.00158)$ \\
Log(market capitalization) & -0.0144 & -0.00329 & -0.0300 & -0.000142 \\
& $(0.0467)$ & $(0.00331)$ & $(0.0245)$ & $(0.00168)$ \\
Equity ratio (book value) & & & & \\
& $-6.306^{*}$ & -0.291 & $2.631^{*}$ & -0.143 \\
Tier 1 Capital Ratio & $(3.603)$ & $(0.268)$ & $(1.346)$ & $(0.113)$ \\
& & & & \\
Constant & 0.0324 & 0.000184 & $0.0551^{* * *}$ & $-0.00293^{*}$ \\
& $(0.0262)$ & $(0.00162)$ & $(0.0163)$ & $(0.00160)$ \\
\hline \hline & & & & \\
adj. $R^{2}$ & 0.00801 & $0.111^{* * *}$ & $-0.809^{* * *}$ & $0.0942^{* * *}$ \\
\hline \hline
\end{tabular}

Robust standard errors in parentheses. ${ }^{*} p<0.10,{ }^{* *} p<0.05,{ }^{* * *} p<0.01$. All covariates are measured in US dollars at the end of Fiscal Year 2006. 
Table 10: Compensation structure and capital requirements

\begin{tabular}{|c|c|c|c|}
\hline & Tier below median & Tier above median & Difference \\
\hline Panel A:Bank level descriptive statistics & & & \\
\hline Total Assets & $\begin{array}{c}432302.2 \\
(608215.4)\end{array}$ & $\begin{array}{c}224976.0 \\
(559489.1)\end{array}$ & 207326.2 \\
\hline Market capitalization & $\begin{array}{c}89518.3 \\
(354227.4)\end{array}$ & $\begin{array}{c}24871.3 \\
(49876.4)\end{array}$ & 64647. \\
\hline Equity (book value) over total asset & $\begin{array}{c}0.0583 \\
(0.0261)\end{array}$ & $\begin{array}{c}0.0823 \\
(0.0334)\end{array}$ & $-0.0240^{* * *}$ \\
\hline Market return from stock prices 2005-2006 & $\begin{array}{c}0.341 \\
(0.159)\end{array}$ & $\begin{array}{c}0.225 \\
(0.305)\end{array}$ & $0.116^{*}$ \\
\hline Tier1 Capital Ratio & $\begin{array}{c}7.519 \\
(0.727) \\
\end{array}$ & $\begin{array}{c}11.56 \\
(3.074)\end{array}$ & $-4.038^{* * *}$ \\
\hline \multicolumn{4}{|l|}{ Panel B: Compensation variables } \\
\hline Cash bonus over salary & $\begin{array}{c}1.907 \\
(2.722)\end{array}$ & $\begin{array}{c}1.280 \\
(2.304)\end{array}$ & 0.627 \\
\hline Equity bonus over salary & $\begin{array}{c}0.897 \\
(2.538)\end{array}$ & $\begin{array}{c}1.946 \\
(4.702)\end{array}$ & -1.050 \\
\hline Total bonus over salary & $\begin{array}{c}2.804 \\
(4.800)\end{array}$ & $\begin{array}{c}3.227 \\
(6.829)\end{array}$ & -0.423 \\
\hline Value of total equity portfolio/Total compensation & $\begin{array}{c}8.353 \\
(22.25)\end{array}$ & $\begin{array}{c}38.62 \\
(140.1)\end{array}$ & -30.26 \\
\hline \multicolumn{4}{|l|}{ Panel C: Perfomance variables in the financial crisis } \\
\hline Buy and hold return 2007-2008 & $\begin{array}{l}-0.583 \\
(0.198)\end{array}$ & $\begin{array}{l}-0.381 \\
(0.230)\end{array}$ & $-0.201^{* * *}$ \\
\hline Standard deviation 2007-2008 & $\begin{array}{c}0.0710 \\
(0.0159) \\
\end{array}$ & $\begin{array}{c}0.0586 \\
(0.0158) \\
\end{array}$ & $0.0124^{* * *}$ \\
\hline$N$ & 50 & 50 & \\
\hline
\end{tabular}

Table 11: Estimation results: Tier 1 capital adequacy ratio

\begin{tabular}{|c|c|c|c|c|}
\hline & \multicolumn{2}{|c|}{ Tier 1 below median } & \multicolumn{2}{|c|}{ Tier 1 above median } \\
\hline Dependent variable & $\begin{array}{c}\text { BHR } \\
(1)\end{array}$ & $\begin{array}{c}\mathrm{RR} \\
(2)\end{array}$ & $\begin{array}{c}\text { BHR } \\
(3)\end{array}$ & $\begin{array}{l}\mathrm{RR} \\
(4)\end{array}$ \\
\hline Cash bonus over salary & $\begin{array}{l}-0.00736 \\
(0.00970)\end{array}$ & $\begin{array}{c}0.00153^{*} \\
(0.000831)\end{array}$ & $\begin{array}{c}0.0169 \\
(0.0112)\end{array}$ & $\begin{array}{l}-0.000388 \\
(0.000791)\end{array}$ \\
\hline Ownership from shares and options & $\begin{array}{c}0.197 \\
(0.643)\end{array}$ & $\begin{array}{c}-0.162^{* * *} \\
(0.0261)\end{array}$ & $\begin{array}{l}-0.408 \\
(0.326)\end{array}$ & $\begin{array}{l}-0.0147 \\
(0.0128)\end{array}$ \\
\hline Equity risk (option vega) & $\begin{array}{l}-1.421 \\
(0.923)\end{array}$ & $\begin{array}{c}0.177^{* *} \\
(0.0742)\end{array}$ & $\begin{array}{c}0.208 \\
(0.854)\end{array}$ & $\begin{array}{l}-0.0655 \\
(0.0875)\end{array}$ \\
\hline Stock market return & $\begin{array}{l}-0.155 \\
(0.156)\end{array}$ & $\begin{array}{c}0.0211^{* *} \\
(0.00862)\end{array}$ & $\begin{array}{c}-0.364^{* * *} \\
(0.101)\end{array}$ & $\begin{array}{l}0.0171^{* * *} \\
(0.00448)\end{array}$ \\
\hline Book to market & $\begin{array}{l}-0.0960 \\
(0.0646)\end{array}$ & $\begin{array}{l}-0.00350 \\
(0.00320)\end{array}$ & $\begin{array}{c}-0.0344^{*} \\
(0.0190)\end{array}$ & $\begin{array}{c}-0.00225^{* *} \\
(0.00109)\end{array}$ \\
\hline Log(market capitalization) & $\begin{array}{l}-0.0299 \\
(0.0228)\end{array}$ & $\begin{array}{r}-0.000781 \\
(0.00119)\end{array}$ & $\begin{array}{r}-0.00426 \\
(0.0209)\end{array}$ & $\begin{array}{c}0.0000366 \\
(0.00147)\end{array}$ \\
\hline Equity ratio (book value) & $\begin{array}{c}1.510 \\
(1.330)\end{array}$ & $\begin{array}{c}-0.246^{*} \\
(0.124)\end{array}$ & $\begin{array}{c}0.815 \\
(1.578)\end{array}$ & $\begin{array}{c}0.145 \\
(0.133)\end{array}$ \\
\hline Tier 1 Capital Ratio & $\begin{array}{l}-0.0170 \\
(0.0431)\end{array}$ & $\begin{array}{l}0.00517^{* *} \\
(0.00243)\end{array}$ & $\begin{array}{c}0.0144 \\
(0.0149)\end{array}$ & $\begin{array}{l}-0.00151 \\
(0.00140)\end{array}$ \\
\hline Constant & $\begin{array}{l}-0.109 \\
(0.347) \\
\end{array}$ & $\begin{array}{c}0.0453^{*} \\
(0.0232)\end{array}$ & $\begin{array}{c}-0.474^{* *} \\
(0.215)\end{array}$ & $\begin{array}{c}0.0634^{* * *} \\
(0.0134)\end{array}$ \\
\hline $\begin{array}{l}N \\
\text { adj. } R^{2}\end{array}$ & $\begin{array}{c}50 \\
0.037\end{array}$ & $\begin{array}{c}50 \\
0.273\end{array}$ & $\begin{array}{c}50 \\
0.186\end{array}$ & $\begin{array}{c}50 \\
0.124\end{array}$ \\
\hline
\end{tabular}

